\title{
Palynology of the Lower Jurassic Rønne Formation on Bornholm, eastern Denmark
}

\author{
EVA B. KOPPELHUS
}

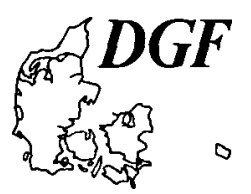

Koppelhus, E. B.: Palynology of the Lower Jurassic Rønne Formation on Bornholm, eastern Denmark. Bull. geol. Soc. Denmark, Vol. 39, pp. 91-109. Copenhagen, December 20th, 1991. https://doi.org/10.37570/bgsd-1991-39-11

\begin{abstract}
Outcrop material from the Lower Jurassic Rønne Formation on the Danish island of Bornholm, in the Baltic Sea, has been investigated palynologically. The 34 samples examined came from sections through the Munkerup, Sose Bugt and Galgeløkke Members, which amount to about $210 \mathrm{~m}$ in stratigraphic thickness in the type area.

The aim of this study was to reevaluate the established stratigraphy defined by Gry (1969) and Gravesen et al. (1982) and characterize the three members by means of palynomorphs. 108 taxa have been recorded of which 67 are spores, 39 are pollen grains and 7 aquatic palynomorphs. Most of these are of little biostratigraphic value but the associations and relative abundances of a small number of selected species can be used to differentiate between the members, and correlations with other sequences elsewhere in Denmark, as well as in southem Sweden (Scania), Germany and Poland are possible. The assemblages from the Munkerup and lower part of the Sose Bugt Members are referred to Lund's (1977) Pinuspolleni-tes - Trachysporites Zone and considered to be of Hettangian age. The upper part of the Sose Bugt and the Galgeløkke Members both correlate with Lund's (1977) unnamed zone with Cerebropollenites macro-verrucosus, now called the Cerebropollenites macroverrucosus Zone (Dybkjær, in press) for which a Sine-murian age has previously been suggested. The Galgeløkke assemblages are more taxonomically im-poverished and poorly preserved than those from the Sose Bugt Member, and there is no palynological evidence to indicate whether they are any younger. They could represent sediments that were deposited at the same time in different environments. The palynological data on all three members of the Rønne Formation support previous environmental interpretations, indicating lacustrine to delta plain conditions of deposition.
\end{abstract}

Eva B. Koppelhus, Geological Survey of Denmark, Thoravej 8, DK-2400 Copenhagen NV, Denmark. November 11th, 1990.

\section{Introduction}

The Rønne Formation was referred to the "Lower Coalbearing Series" by Gry (1969). It was formally established as a formation by Gravesen et al. (1982) who subdivided it into the Munkerup, Sose Bugt and Galgeløkke Members (fig. 1). The sediments of which these are composed were deposited under deltaic conditions. They are exposed on the southwestern coast of Bornholm on the Rønne-Hasle and ArnagerSose Blocks (fig. 2). Between 150 and $210 \mathrm{~m}$ of the Galgeløkke Member and approximately 240 $m$ of the Sose Bugt Member are present on the Rønne-Hasle Block (fig. 2); it is not known whether the Munkerup Member is present there. On the Arnager-Sose Block the Sose Bugt and Munkerup Members are present, but their total thickness is somewhat less, being around $60 \mathrm{~m}$ (Gravesen et al. 1982).

All of the samples from the Munkerup and
Sose Bugt Members have come from the Arnager-Sose Block whereas those from the Galgeløkke Member are from the Rønne-Hasle Block. It is not known what underlies the Rønne Formation on the Rønne-Hasle Block, but on the Arnager-Sose Block it rests upon the Kågerød Formation (Risebæk Member), dated on the basis of a sparse ostracod fauna as late Ladinian-Carnian (Christensen, 1972). It is overlain by the Hasle Formation, the transition being marked by a

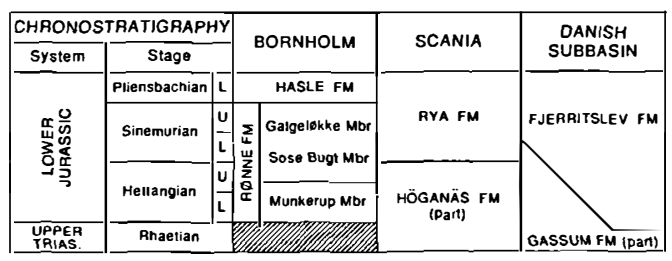

Fig. 1. Chrono- and lithostratigraphy of the Mesozoic succession on Bornholm, in Scania and in the Danish Subbasin; compiled from Gravesen et al. (1982), Sivhed (1984) and Michelsen (1989). 


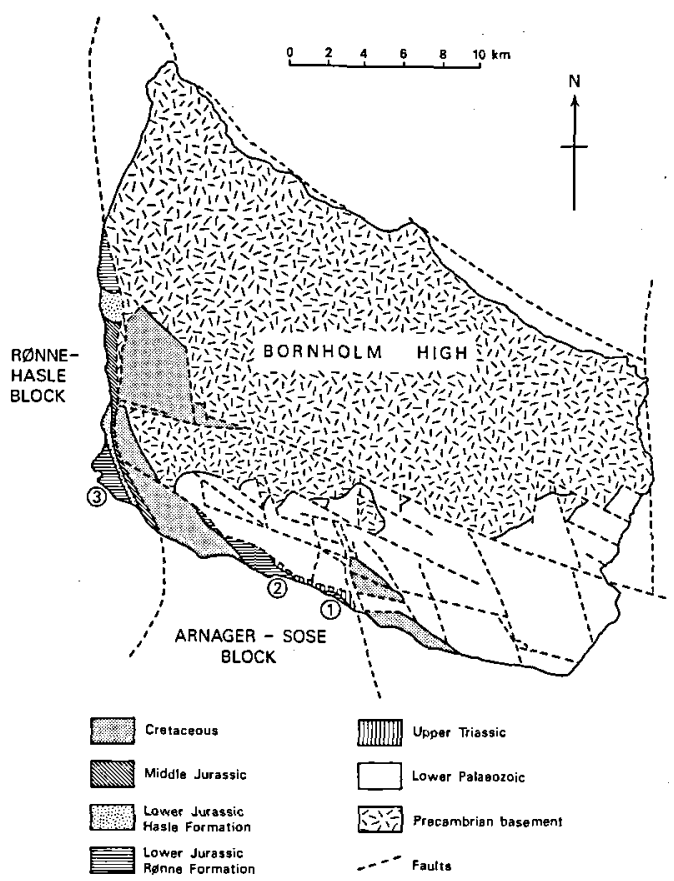

Fig. 2. Geological map of Bornholm with the sampling localities indicated; after Gravesen et al. (1982). 1: Munkerup Member, 2: Sose Bugt Member, 3: Galgeløkke Member.

change from unconsolidated interbedded sand and clay to a limonitic brown to grey sandstone of early Pliensbachian age (Gravesen et al. 1982; Surlyk \& Noe Nygaard 1986).

The Rønne Formation has previously been dated as Early Jurassic. The oldest part, namely the Munkerup Member, contains a Thaumatopteris flora of "Liassic" (Hettangian) age (Harris, 1937). It was referred to the Lower Lias by Gry (1969) on basis of the abundant occurrence of Nathorstisporites hopliticus Jung, 1958 together with other megaspores such as Verrutriletes franconicus Jung, 1960, Horstisporites areolatus (Harris, 1935) Potonié, 1956 and Horstisporites harrisii (Murray, 1939) Potonié, 1956.

The Sose Bugt Member was also referred to the Lias (Lias alpha: Hettangian to earliest Sinemurian) by Gry (1969) because of the presence of the megaspore species Verrutriletes franconicus, Trileites turbanaeformis (Harris, 1961) Marcinkiewicz, 1971, Horstisporites areolatus and Hortisporites harrisii in samples taken from this part of the succession.

Except for an occurrence of the bivalve Cardinia follini Lundgren (now Eomiodon menkei (Huckriede 1967)) at Galgeløkke, and of plant fossils referable to Dictyophyllum at Ormebæk, the Galgeløkke Member has been regarded as essentially unfossiliferous (Grönwall \& Milthers, 1916; Gravesen et al., 1982). Neither these named fossils nor the occurrence of rare agglutinating foraminifers (Sellwood, 1972) and locally abundant trace fossils (Rolle, 1978) are of much biostratigraphic value. Its age has, therefore, previously been suggested solely on the basis of its stratigraphic position between the Sose Bugt Member and the Hasle Formation (Gry, 1969).

\section{Material and methods}

Seven samples were taken from an exposure of the Munkerup Member on the south coast of Bornholm close to Stangegård (fig. 2). The dominant lithology at this locality is grey to black clay with subordinate thin bands of red, brown and white clay and sandstone (Gravesen et al. 1982). Eighteen horizons were sampled from the type locality of the Sose Bugt Member on the south coast between Sose Odde and Lilleå (fig. 2; for details see fig. 6 in Gravesen et al. 1982); their lithologies vary from generally poorly consolidated sand to equally soft silt and mud. Nine samples were taken from exposures of the Galgeløkke Member along the southwestern coast close to the town of Rønne. The lithologies of these are mostly dominated by heterolithic sand, wavy and flaser-laminated sand and clay.

All 34 samples were processed for their palynological content using the standard techniques developed at the Geological Survey of Denmark (Poulsen et al. 1990). Several slides of each preparation were examined by transmitted light microscopy. These have now been deposited in the collections of the Department of Stratigraphy at the Geological Survey of Denmark (DGU).

For each sample 200 specimens were counted from one or two slides, after which only those species not previously encountered were registered; these are indicated as "very rare" on the abundance range-charts (figs 3 and 4 ). The preservation of the palynomorphs from all three members is generally very good. Their colour is light yellow, except for those reworked from the Carboniferous which are dark brown (for discussion and illustrations of the reworked palynomorphs, see Nielsen \& Koppelhus, 1991). 


\section{Systematic palynology}

\section{Palynomorph taxa}

For convenience of reference the taxa recorded from the three members (see figs 3 and 4) are listed under three subheadings: miospores, phytoplankton and reworked palynomorphs. All are accompanied by author attributions and dates. In addition, figure references are given alongside all of the forms illustrated in this paper. These are arranged on figures 7-12 approximately according to morphological type. In common with the other palynomorphs, the miospores are, however, listed in alphabetical order and not according to Potonié's (1956 and later papers) classification because this serves no useful purpose here. Those taxa preceded by an asterisk are discussed in the following section.

\section{Miospores:}

Acanthotriletes varius Nilsson, 1958 Alisporites grandis (Cookson) Dettmann, 1963

A. microsaccus (Couper) Pocock, 1962

A. radialis (Leschik) Lund, 1977

A. robustus Nilsson, 1958

A. thomasii (Couper) Nilsson, 1958

Anapiculatisporites spiniger (Leschik)

Reinhardt, 1961

Annulispora folliculosa (Rogalska) de Jersey, 1959: fig. $9 \mathrm{e}$

$A$. sp. cf. A. folliculosa

Apiculatisporis parvispinosus (Leschik) Schulz, 1962

A. ovalis (Nilsson) Norris, 1965

Aratrisporites minimus Schulz, 1967: fig. 10c

A. parvispinosus Leschik, 1955: fig. 10d

Araucariacites australis Cookson, 1947

Baculatisporites comaumensis (Cookson)

Potonié, 1956

B. wellmanii (Couper) Krutzsch, 1959

Calamospora tener (Leschik) Mädler, 1964a:

fig. $7 \mathrm{~b}$

Camarozonosporites golzowensis Schulz, 1967:

$9 \mathbf{i}$

Cerebropollenites macroverrucosus (Thiergart)

Schulz, 1967: fig. 11 b

C. thiergartii Schulz, 1967: fig. 11 a

Chasmatosporites apertus Nilsson, 1958: fig. $11 \mathrm{e}$

C. elegans Nilsson, 1958
C. hians Nilsson, 1958: fig. $11 \mathrm{~d}$

C. major Nilsson, 1958

C. minor Nilsson, 1958

C. spp.

Chomotriletes spp.

Cibotiumspora jurienensis (Balme) Filatoff, 1975

* Cingutriletes infrapunctus (Schulz) comb. nov.: fig. $9 \mathrm{j}$

Clavatipollenites hughesii Couper, 1958 sensu

Schulz 1967: fig. $11 \mathrm{~g}$

Conbaculatisporites mesozoicus Klaus, 1960

C. spinosus (Mädler) Lund, 1977

Corollina torosus (Reissinger) Cornet \&

Traverse, 1975: fig. $11 \mathrm{f}$

C. spp.

Deltoidospora minor (Couper) Pocock, 1970

D. toralis (Leschik) Lund, 1977: fig. 7 a

D. spp.

Densoisporites velatus Weyland \& Krieger, 1953

* Dicyclosporis bicollateralis (Rogalska) comb. nov.: figs $7 \mathrm{~g}, \mathrm{j}$

${ }^{*} D$. pseudoverrucatus (Schulz) comb. nov.: figs

$7 \mathrm{~h}, \mathrm{i}$

* D. radiatus (Schulz) Jansonius \& Hills 1990:

fig. $7 \mathrm{e}, \mathrm{f}$

* Distcyclosporis trizonatus (Schulz) Jansonius

\& Hills 1990: fig. 7k

Eucommiidites major Schulz, 1967

E. troedssonii Erdtman, 1948

Iraqispora labrata Singh, 1964: fig. $8 \mathrm{e}$

${ }^{*}$ Kraeuselisporites reissingeri (Harris) Morbey, 1975: fig. 9d

Laevigatosporites dubius Nilsson, 1958: fig. 91

L. mesozoicus Schulz, 1967

Lycopodiacidites infragranulatus Mädler, 1964b

L. rugulatus (Couper) Schulz, 1967

Marattisporites scabratus Couper, 1958: fig. $9 \mathrm{k}$

* "Monosaccates": cf. Paleopicea glaesaria

Bolkhovitina, 1956: fig. $10 \mathrm{a}$

Monosulcites punctatus Orlowska-Zwolinska, 1966

Ovalipollis ovalis Krutzsch, 1955: fig. 10 b

* Peltandripites sp. cf. P. tener Norris, 1969: fig. $11 \mathrm{~h}$

Perinopollenites elatoides Couper, 1958: fig. $10 \mathrm{f}$

Pinuspollenites minimus (Couper) Kemp, 1970:

fig. $10 \mathrm{~g}$

P. pinoides (Nilsson) Lund, 1977

Podocarpidites spp. 


\section{RØNNE FORMATION}

RANGE CHART OF GRAPHIC ABUNDANCES BY LOWEST APPEARANCE

Key to Symbols

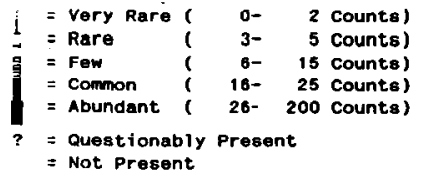

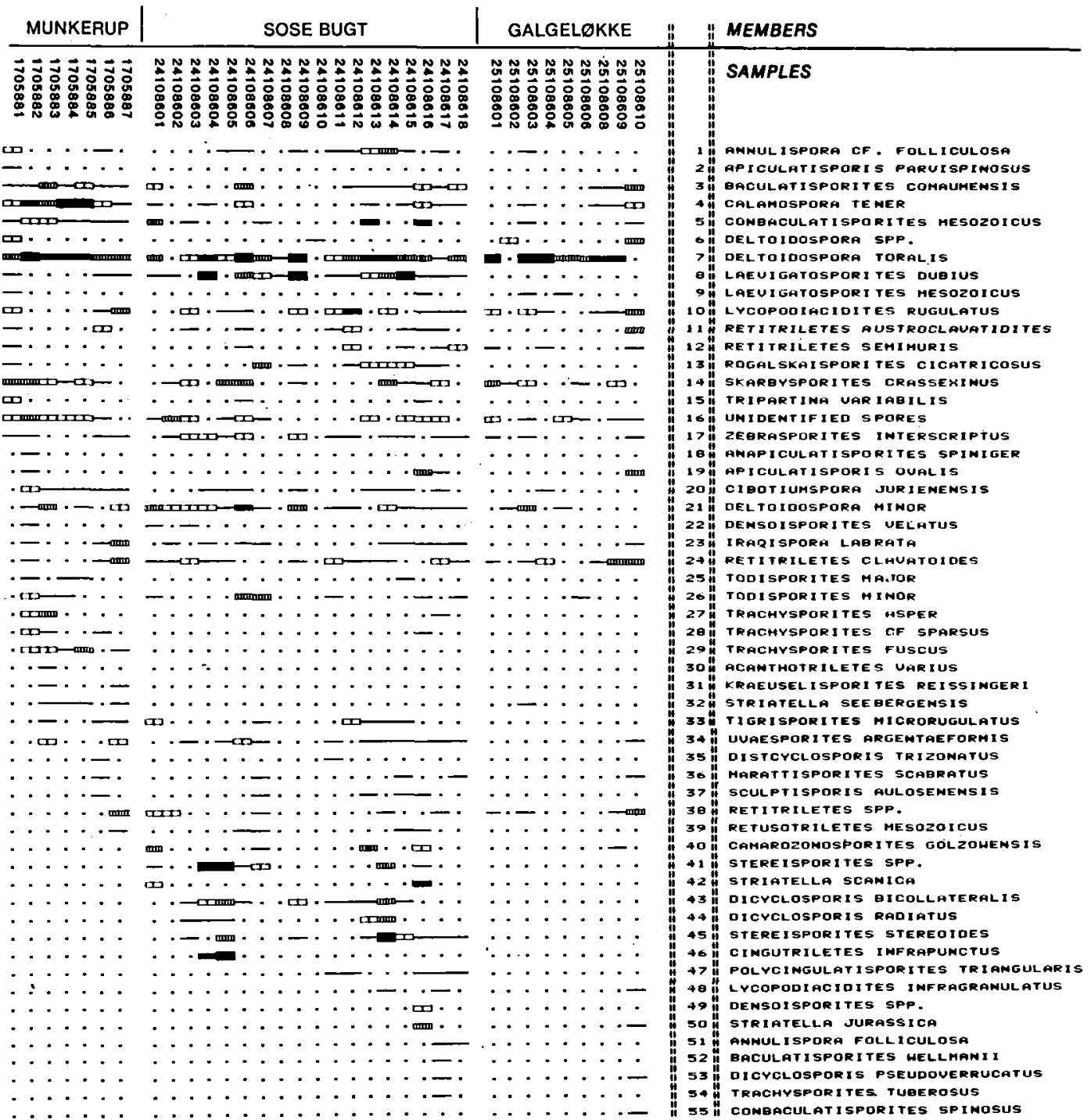

Fig. 3 a. For caption see fig. 3 b. 

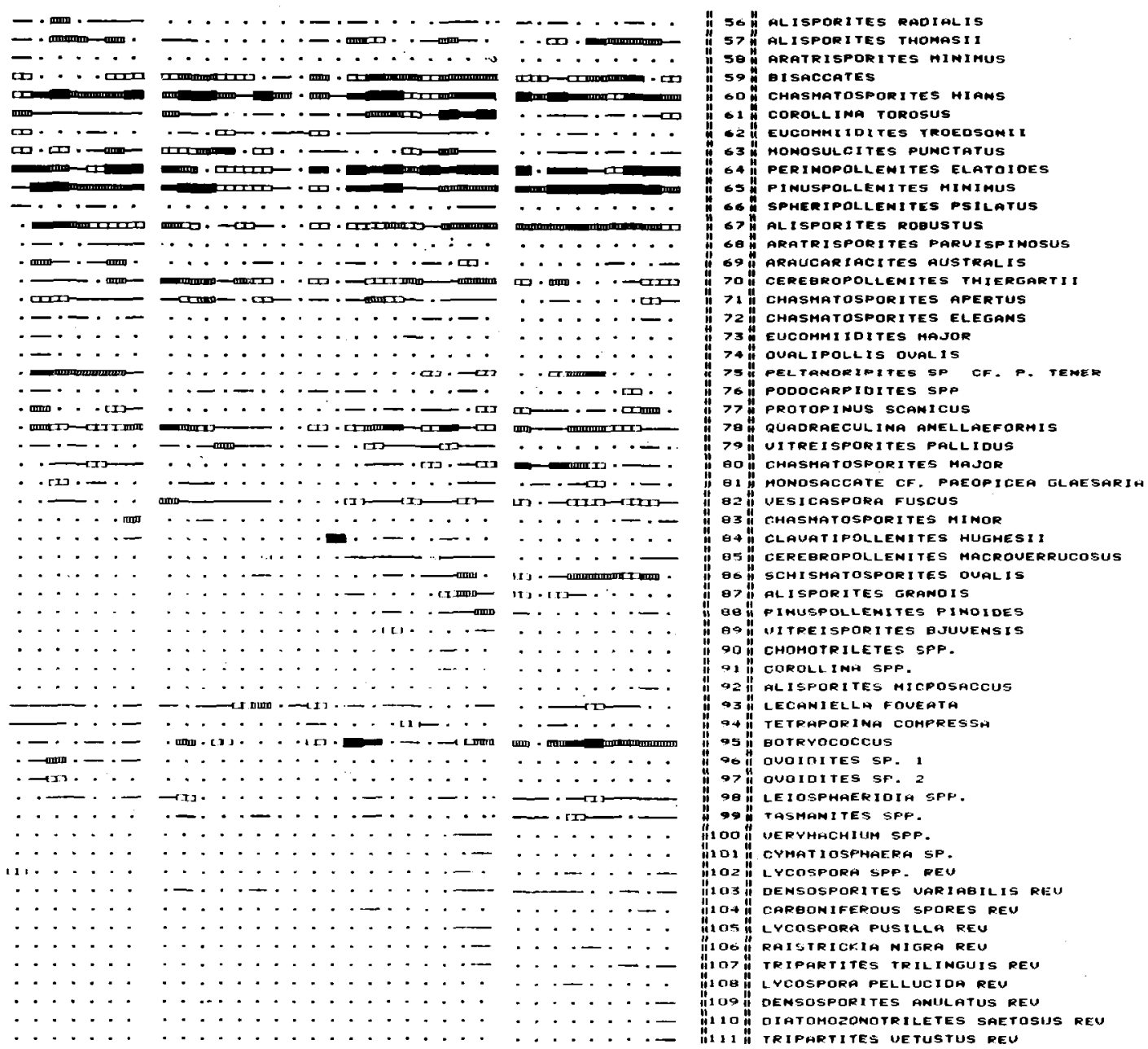

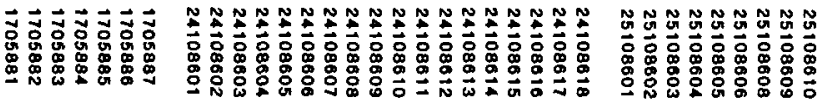

Fig. 3 b. Composite range chart of all the species recorded. Although the members are plotted as if in stratigraphic order following Gravesen et al. (1982), it is accepted that the sequences may be, at least partly, diachronous. This applies particularly to the upper part of the Sose Bugt and Galgeløkke Members; hence the spaces between the data-sets. The "unidentified spores" category (16) was used mainly for forms which are too poorly preserved to be identified with confidence, but it also includes a few rare morphotypes (single specimens) that are not closely comparable to any known, previously published taxa. Rev. = reworked spores.

Polycingulatisporites triangularis (Bolkhovitina)

Playford \& Dettmann, 1965: figs $9 \mathrm{~g}, \mathrm{~h}$

Protopinus scanicus Nilsson, 1958

Quadraeculina anellaeformis Malyavkina, 1949:

fig. $10 \mathrm{e}$

Retitriletes austroclavatidites (Cookson) Döring, Krutzsch, Mai \& Schulz, 1963

$R$. clavatoides (Couper) Döring, Krutzsch, Mai \& Schulz, 1963: fig. 8i

R. semimuris (Danzé-Corsin \& Laveine)

McKellar, 1974: figs $8 \mathrm{j}, \mathrm{k}$
$R$. spp.

Retusotriletes mesozoicus Klaus, 1960

Rogalskaisporites cicatricosus (Rogalska)

Danzé-Corsin \& Laveine, 1963: fig. 7d

Schismatosporites ovalis Nilsson, 1958

* Sculptisporis aulosenensis (Schulz) comb.

nov.: fig. $7 \mathrm{c}$

Skarbysporites crassexinus (Nilsson) Lund \&

Ecke, 1988

Spheripollenites psilatus Couper, 1958

Stereisporites spp. 


\section{RØNNE FORMATION}

RANGE CHART OF PRESENCE/ABSENCE BY LONEST APPEARANCE

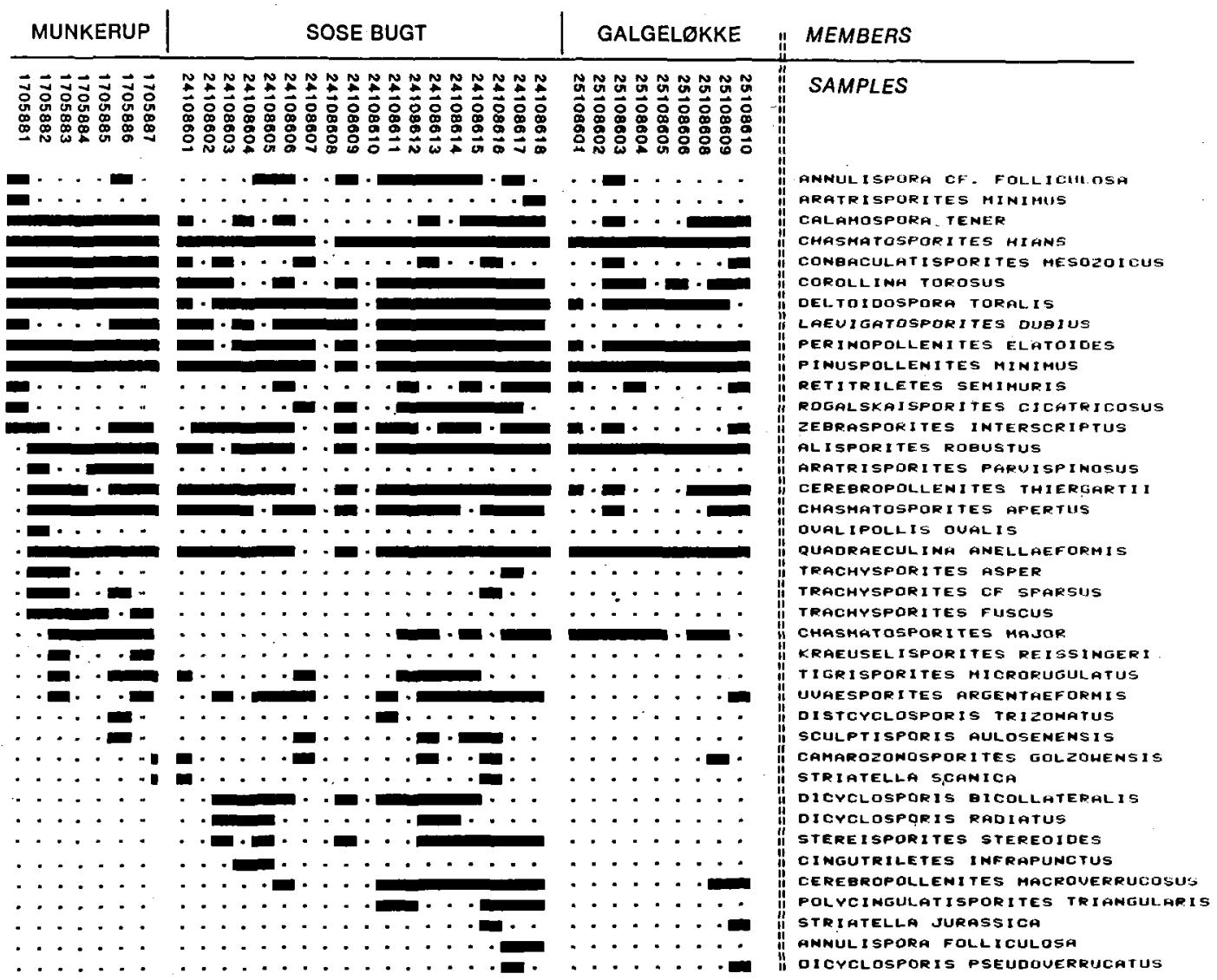

Fig. 4. Range chart of the stratigraphically important species: see explanation of figure 3 for comments on the stratigraphy.

S. stereoides (Potonié \& Venitz) Pflug in

Thomson \& Pflug, 1953: fig. 71

* Striatella jurassica Mädler, 1964b

${ }^{*}$ S. scanica (Nilsson) Filatoff \& Price, 1988:

figs 9 a, b

${ }^{*}$ S. seebergensis Mädler, 1964b: fig. 9 c

* Tigrisporites microrugulatus Schulz, 1967: figs

$8 \mathrm{f}, \mathrm{g}$

Todisporites major Couper, 1958

T. minor Couper, 1958

Trachysporites asper Nilsson, 1958: fig. 8c

T. fuscus Nilsson, 1958: fig. $8 \mathrm{~d}$

T. sp. cf. T. sparsus (Bharadwaj \& Singh)

Lund, 1977: fig. $8 \mathrm{~h}$

T. tuberosus Nilsson, 1958

Tripartina variabilis Malyavkina, 1949

Uvaesporites argenteaeformis (Bolkhovitina)

Schulz, 1967: figs $8 \mathrm{a}, \mathrm{b}$
Vesicaspora fuscus (Pautsch) Morbey, 1975

Vitreisporites bjuvensis Nilsson, 1958

$V$. pallidus (Reissinger) Nilsson, 1958

Zebrasporites interscriptus (Thiergart) Klaus, 1960: fig. $9 \mathrm{f}$

Phytoplankton:

${ }^{*}$ Botryococcus spp.: fig. $12 \mathrm{~d}$

* Cymatiosphaera sp. fig. $12 \mathrm{e}$

${ }^{*}$ Lecaniella foveata Singh, 1971: fig. 12 b

Leiosphaeridia spp.

* Ovoidites sp. 1: fig. 12 a

*O. sp. 2: fig. $12 \mathrm{c}$

Tasmanites sp.

* Tetraporina compressa Kondrat'ev, 1963: fig.

$11 \mathrm{i}$

Veryhachium spp. 


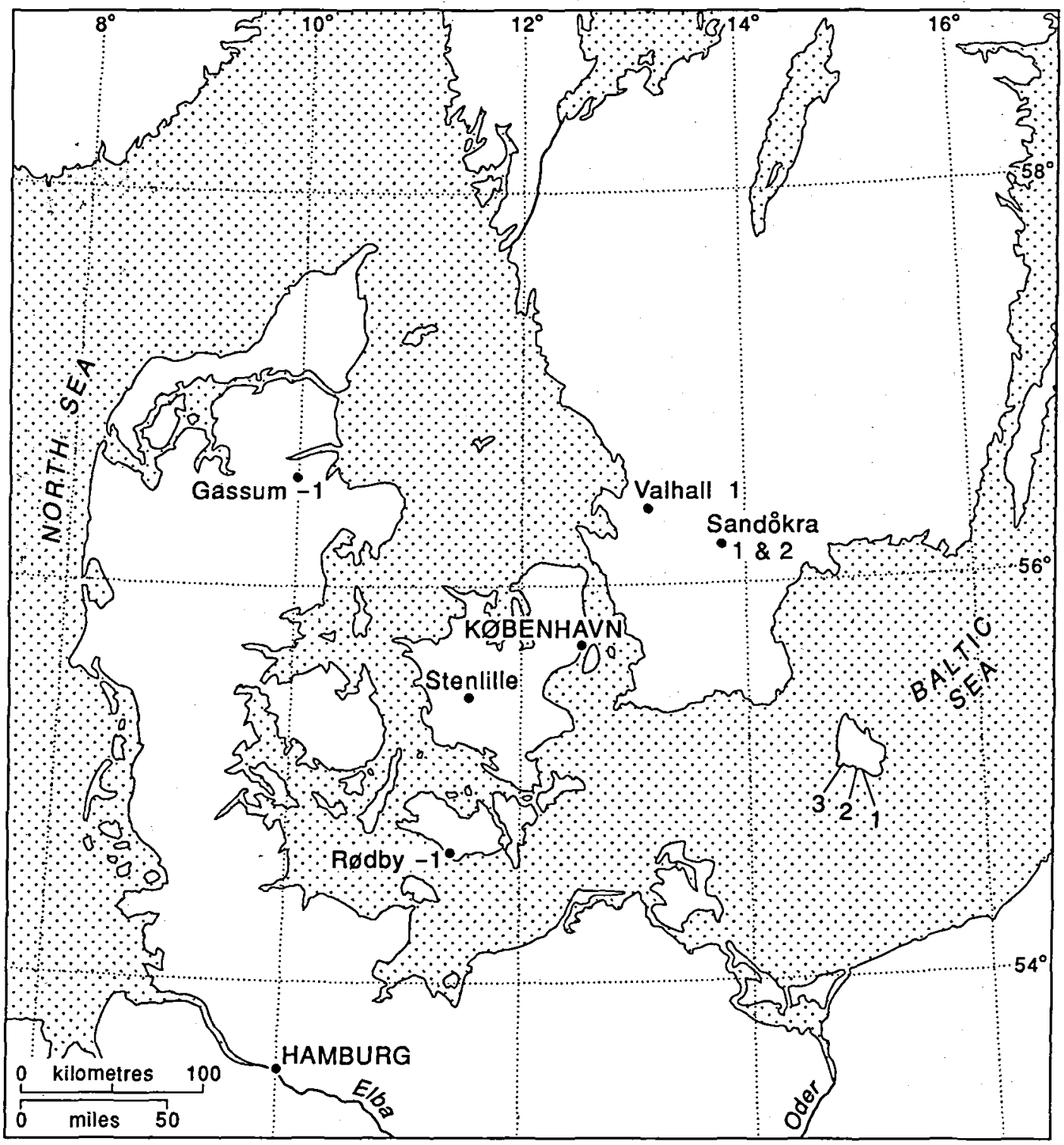

Fig. 5. Map of Denmark and surrounding areas shiuwing the location of the boreholes referred to in the text.

Fig. 6. Correlation of the three members of the Rønne Formation with standard Lower Jurassic stages, based on palynological data.

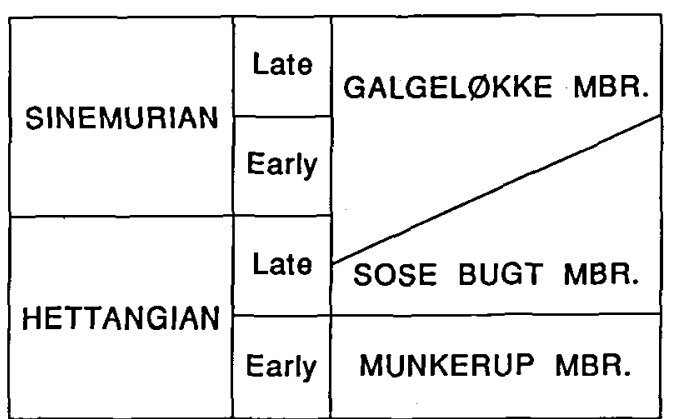



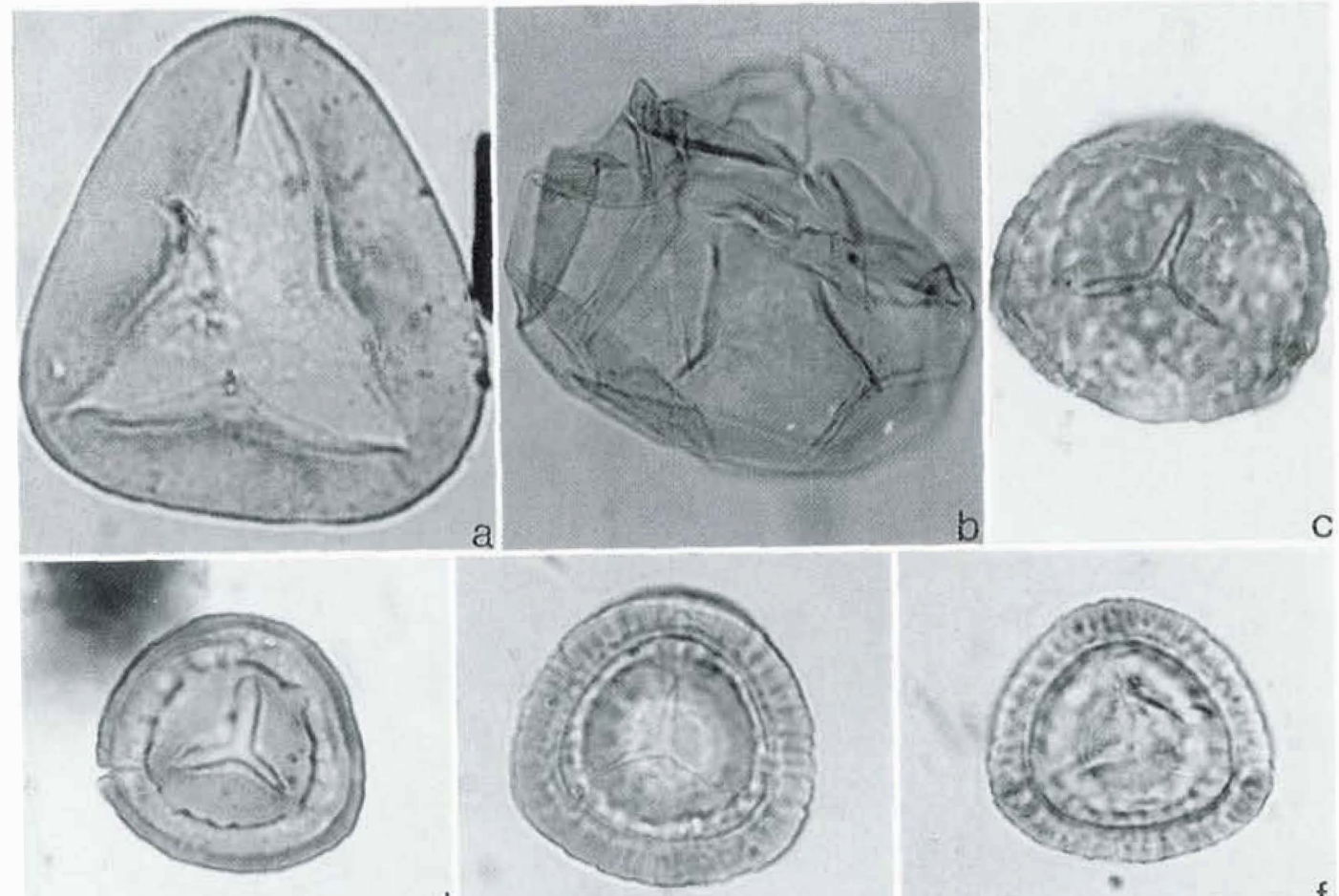

d

e
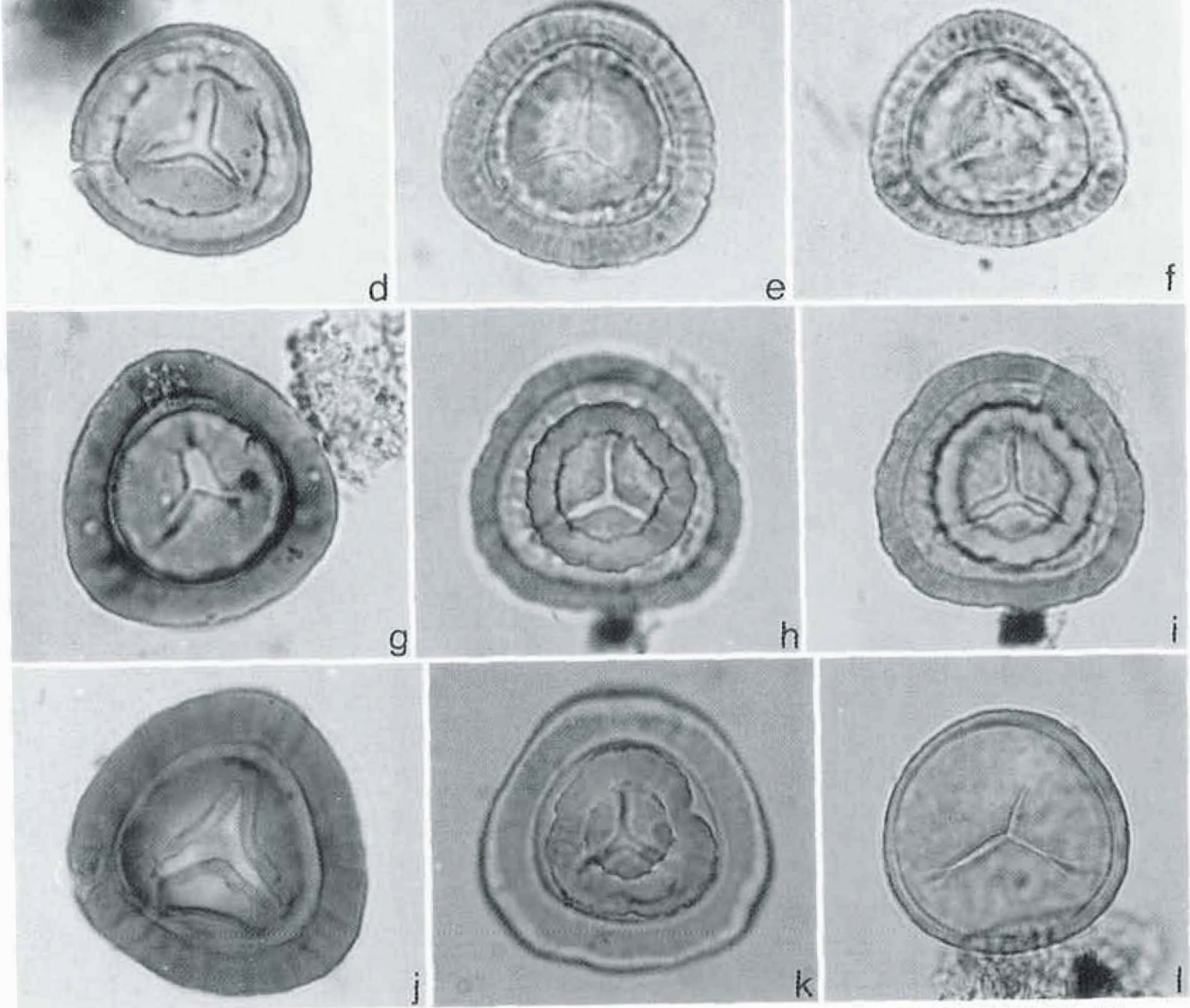

Fig. 7. Deltoidospora toratis (Leschik) Lund. Sose Bugt Mbr. (sample 241086-9-1). DGU Cat. No. 1991-EBK-1. b; Calamospora

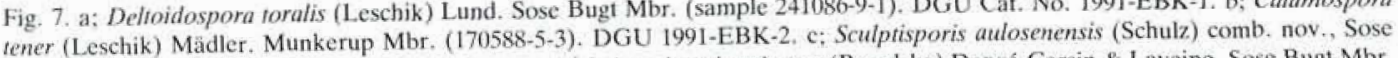
tener (Leschik) Madler. Munkerup Mbr. (17-385-5-3). Dalskispories cicaricosus (Rogalska) Danze-Corsin \& Laveine, Sose Bugt Mbr. Bugt Mbr. (241086-13-1). DGU 1991-EBK-3, d; Rogalskasparis (Schulz) Jansonius \& Hills. Sose Bugt Mbr. (241086-9-2). DGU (241086-13-1). DGU 1991-EBK-4. e \& f; Dicyclosporis radiatus (Schulz) Jansonius \& 1991-EBK-5. h \& i; Dicyclosports preudovernicatus (Schulz) comb. nov. Galgelokke Mbr. (241066-10-3). DGU 19rosoris trizonatus Dicyclosporis bicollateralis (Rogalska) comb. nov. Sose Bugt Mbr. (241086-11-2). Detites stereoides (Potonie \& Venitz) Pflug. Sose (Schulz) comb. nov. Sose Bugi Mbr. (241086-)

Bugt Mbr. (241086-9-2). DGU $1991-\mathrm{EBK}$
Comments relevant to figures 7 to 12 .

All magnifications are approximately $\times 1000$. Sample and slide numbers and DGU catalogue numbers are indicated for each of the fllustrated specimens. 

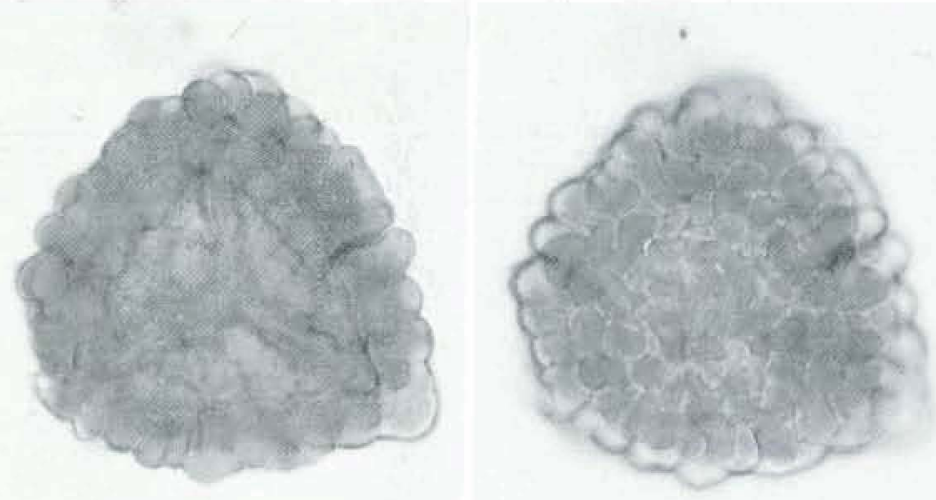

a

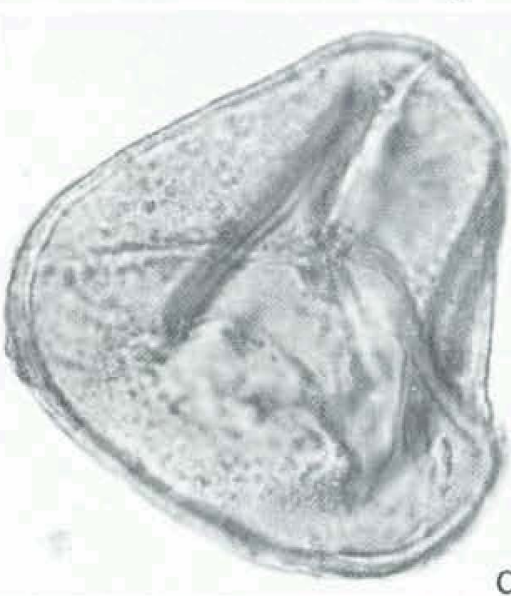

b

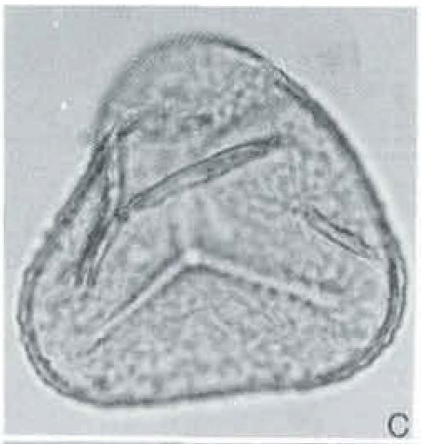

C
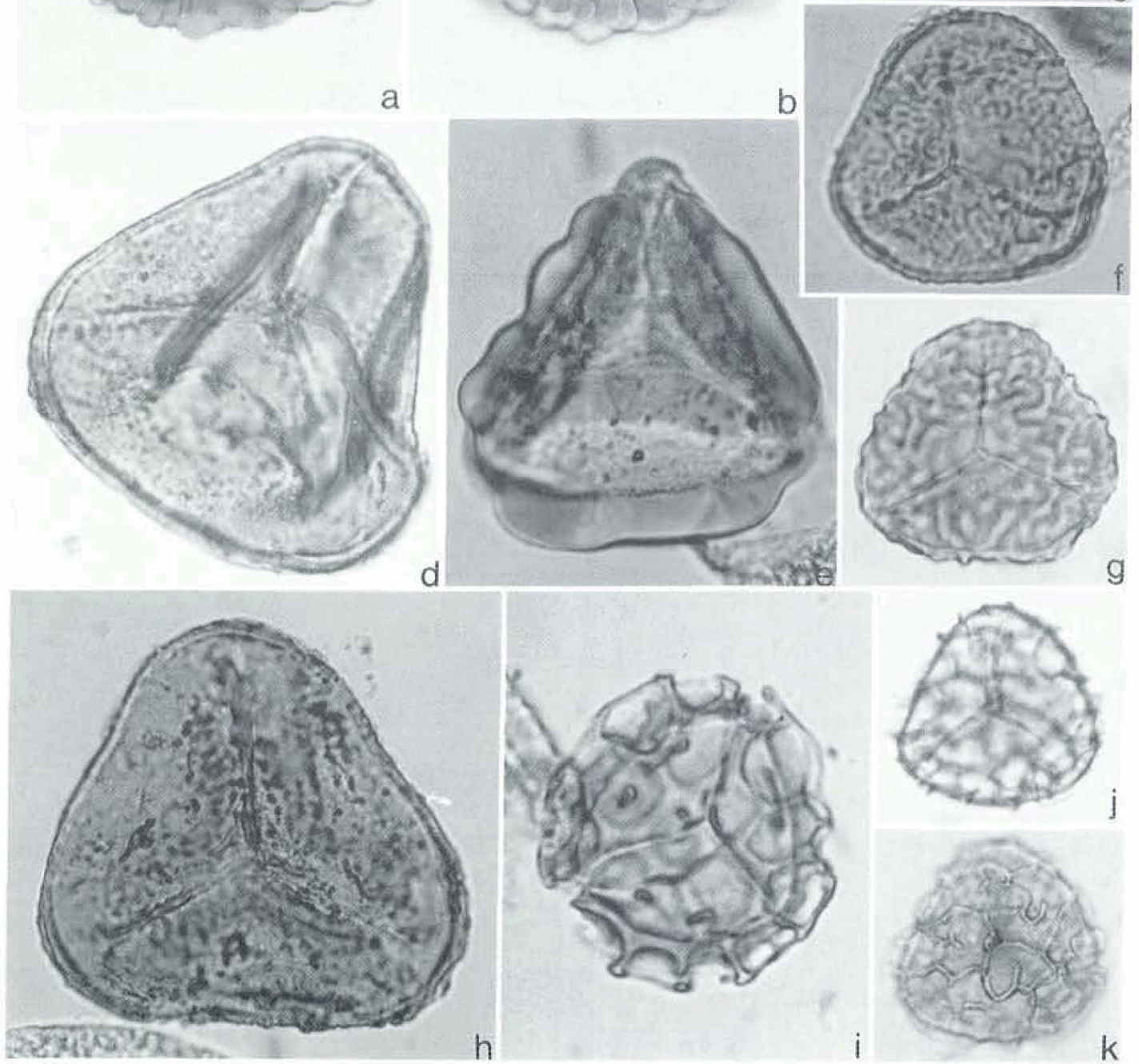

Fig. 8. a \& b; Uvaesporites argenteaeformis (Bolkhovitina) Schulz. Sose Bugt Mbr. (241086-11-1). DGU 1991-EBK-10. c; Trachysporites asper Nilsson. Sose Bugt Mbr. (241086-18-1). DGU 1991-EBK-11. d; Trachysporites fuscas Nilsson. Munkerup Mbr. (1705885-3). DGU 1991-EBK-12. e; Iraqispora labrata Singh. Munkerup Mbr. (180588-2-3). DGU 1991-EBK-13, f \& g: Tigrisporites microrugulatus Schulz. Munkerup Mbr. (180588-1-3). DGU 1991-EBK-14. h; Trachysporites sp. cf. T. sparsus (Bharadwaj \& Singh) Lund. Munkerup Mbr. (170588-2-3). DGU 1991-EBK-15. i: Retitriletes clavatoides (Couper) Döring, Krutszch, Mai \& Schulz. Sose Bugt Mbr. (241086-9-1). DGU 1991-EBK-16. j\& k: Retitriletes semimuris (Danzé-Corsin \& Laveine) McKellar. Sose Bugt Mbr. (24108611-2), DGU 1991-EBK-17. 

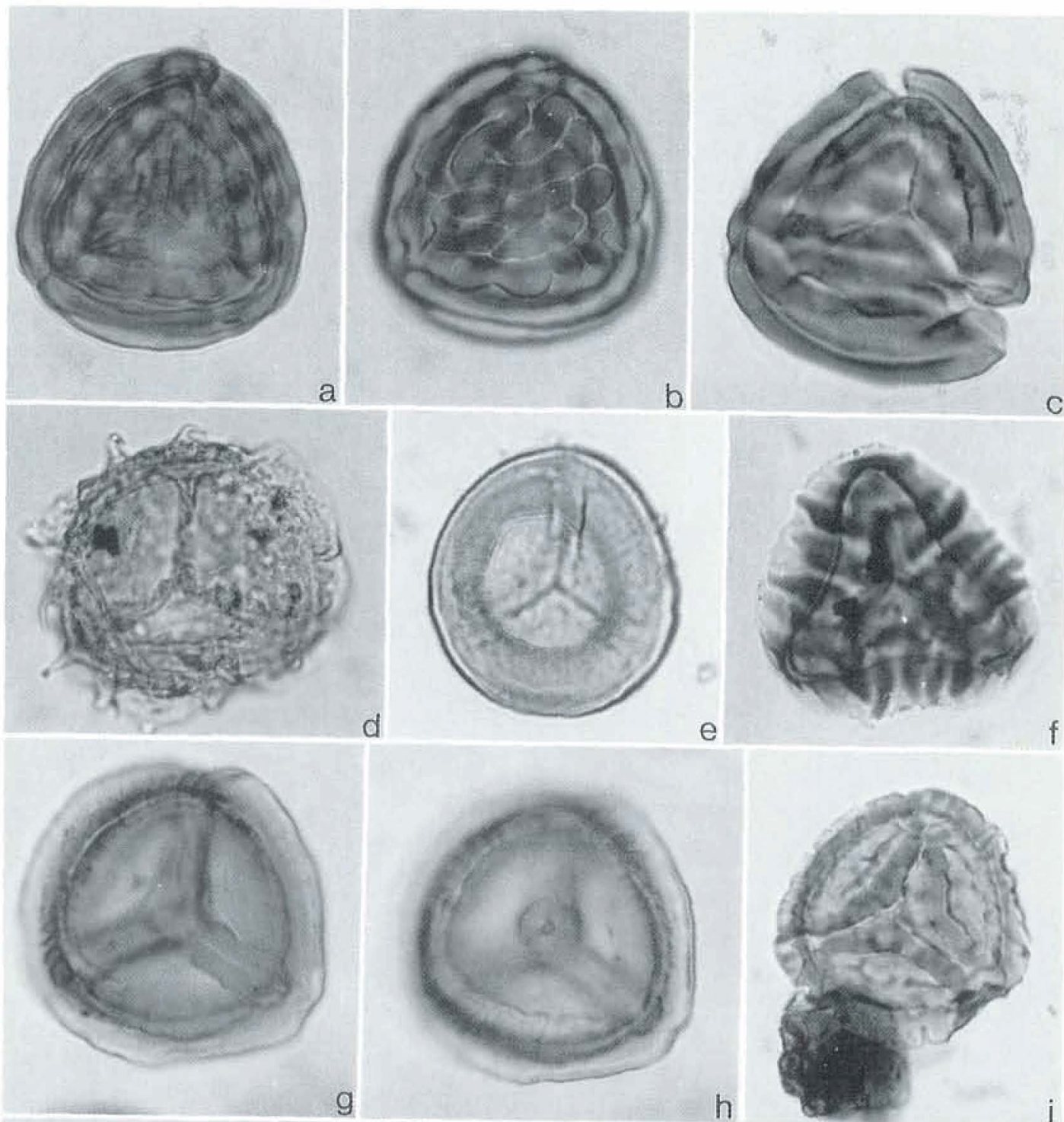

h
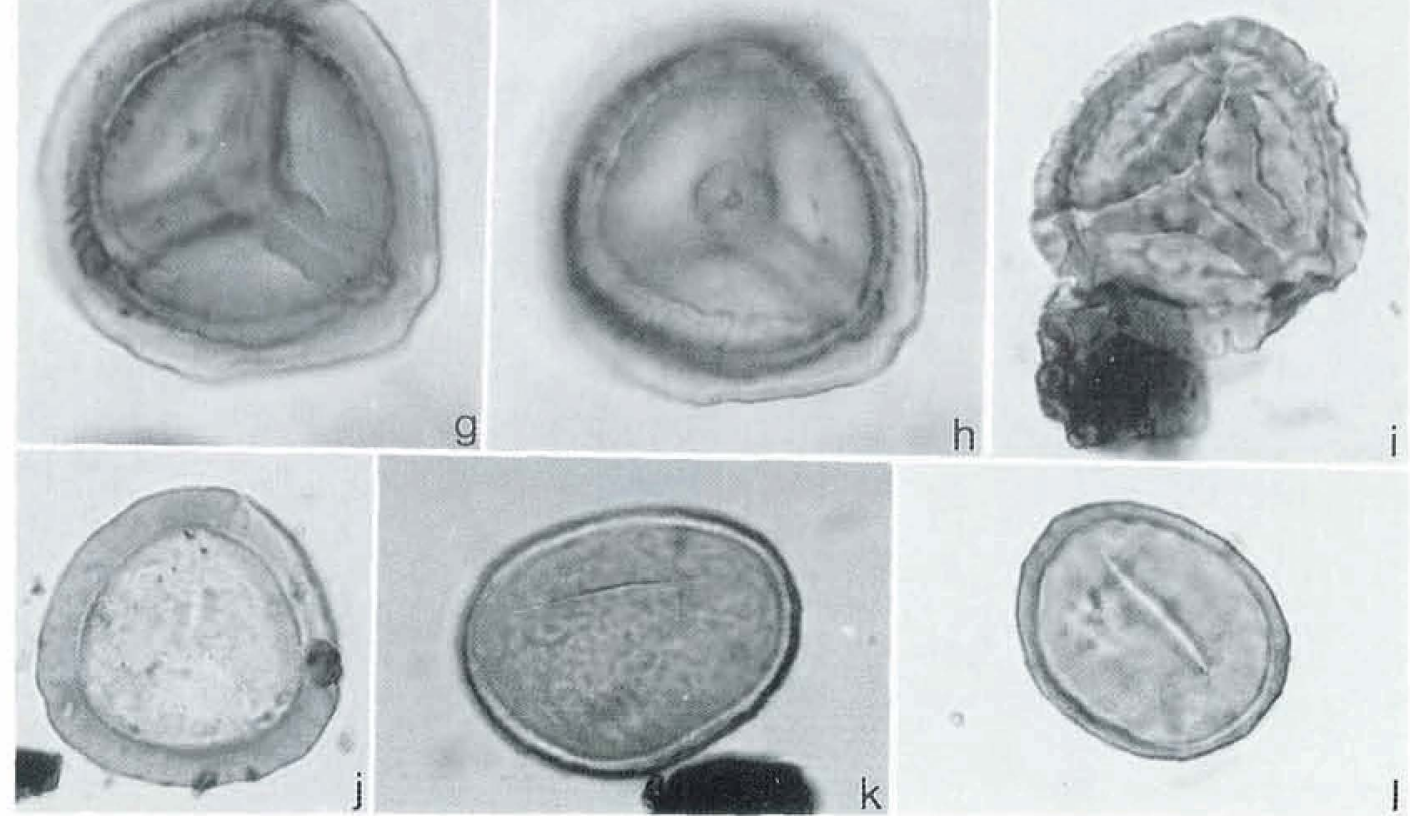

Fig. 9. a \& b; Striatella scanica (Nilsson) Filatoff \& Price. Sose Bugt Mbr. (241086-16-1). DGU 1991-EBK-18. c; Striatella seebergensis Mädler. Sose Bugt Mbr. (241086-12-2). DGU 1991-EBK-19. d; Kraeuselisporites reissingeri (Harris) Morbey. Munkerup Mbr. (180588-2-3). DGU 1991-EBK-20. e; Annulispora folliculosa (Rogalska) De Jersey. Sose Bugt Mbr. (241086-9-2). DGU 1991EBK-21. f: Zebrasporites interscriptus (Thiergart) Klaus. Sose Bugt Mbr. (241086-11-2). DGU 1991-EBK-22. g \& h; Polycingularisporites triangularis (Bolkhovitina) Playford \& Dettmann. Sose Bugt Mbr. (241086-16-1). DGU 1991-EBK-23. 1; Camarozonosporites golzowensis Schulz. Sose Bugt Mbr. (241086-13-1). DGU 1991-EBK-24. j; Cingutriletes infrapunctus (Schulz) comb. nov. Sose Bugt Mbr. (241086-5-1). DGU 1991-EBK-25. k; Maratisporites scabratus Couper. Sose Bugt Mbr. (241086-9-1). DGU 1991-EBK-26. 1; Laevigatosporites dubius Nilsson. Sose Bugt Mbr. (241086-13-1). DGU 1991-EBK-27. 

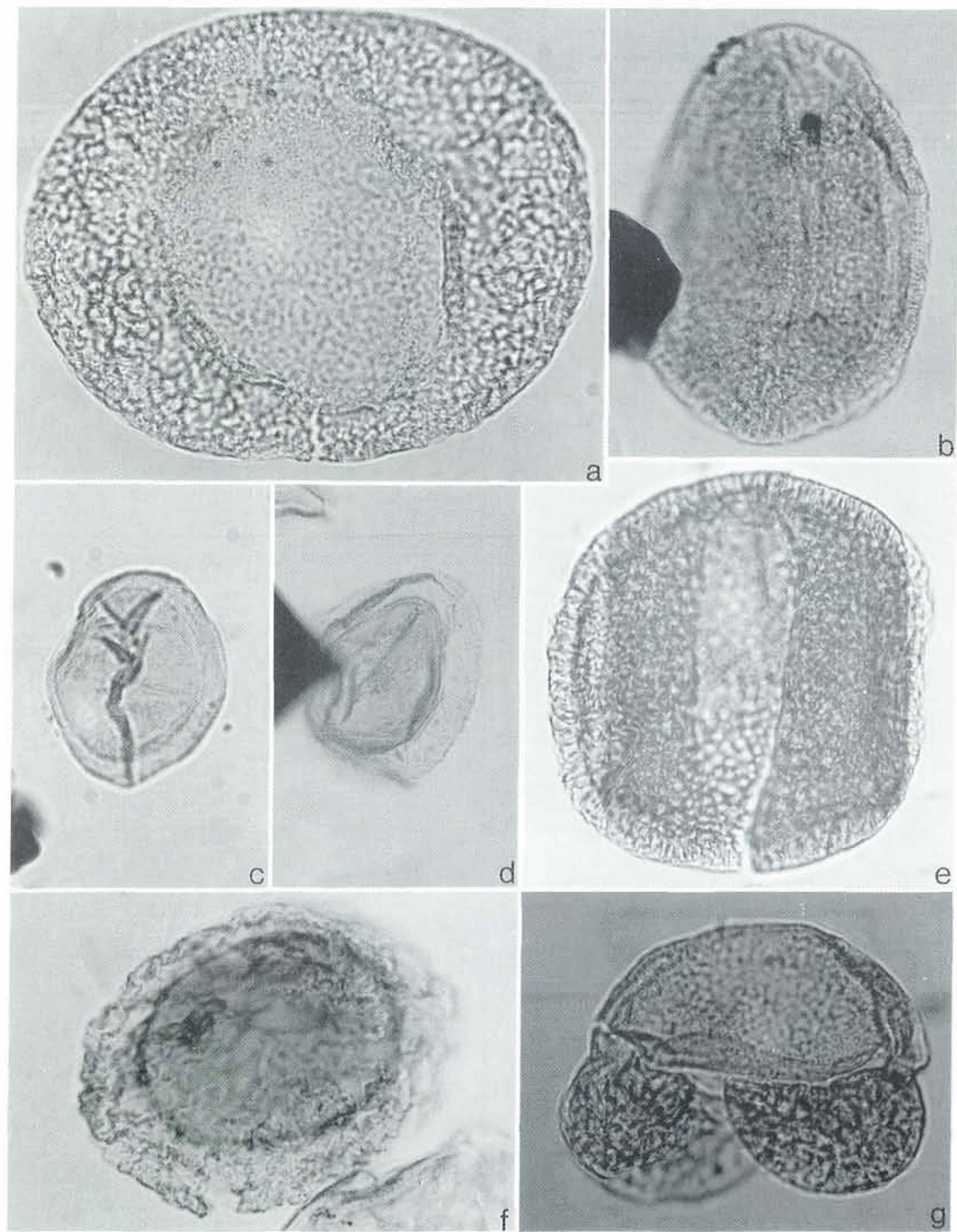

Fig. 10. a: Monosaccate, cf. Paleopicea glaesaria Bolkhovitina. Munkerup Mbr. (170588-2-3). DGU 1991-EBK-28. b: Ovalipollis ovalis Krutzsch. Sose Bugt Mbr. (241086-17-1). DGU 1991-EBK-29. c; Aratrisporites minimus Schulz. Sose Bugt Mbr. (241086-18-1). DGU 1991-EBK-30. d; Aratrisporites parvispinosus Leschik. Munkerup Mbr. (180588-2-3). DGU 1991-EBK-31. e; Quadraeculina anellaeformis Malyavkina. Munkerup Mbr. (170588-2-3). DGU 1991-EBK-32. f; Perinopollenites elaroides Couper. Sose Bugt Mbr. (241086-9-2). DGU 1991-EBK-33. g; Pinuspollenites minimus (Couper) Kemp. Munkerup Mbr. (170588-2-3). DGU 1991-EBK-34. 


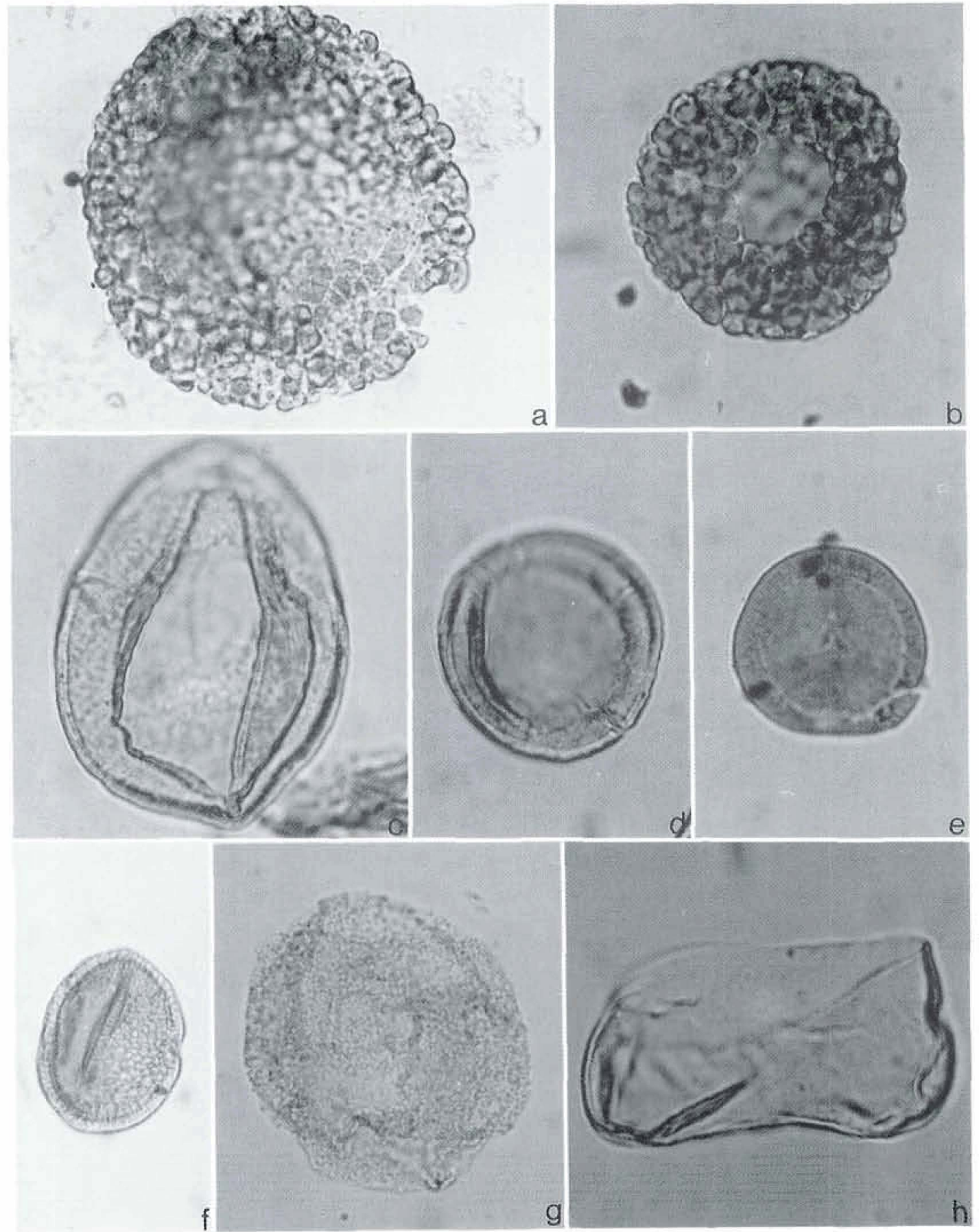

Fig. 11. a: Cerebropollenites thiergartii Schulz. Sose Bugt Mbr. (241086-9-2). DGU 1991-EBK-35. b; Cerebropollenites macroverncosus (Thiergart) Schulz. Sose Bugt Mbr. (241086-11-1). DGU 1991-EBK-36. c; Chasmatosporites hians Nilsson. Munkerup Mbr. (170588-2-3). DGU 1991-EBK-37. d; Chasmatosporites apertus Nilsson. Munkerup Mbr. (170588-2-3). DGU 1991-EBK-38. e; Corollina torosus (Reissinger) Cornet \& Traverse. Sose Bugt Mbr. (241086-16-1). DGU 1991-EBK-39. f; Clavatipollenites hughesii Couper. Sose Bugt Mbr. (241086-13-1). DGU 1991-EBK-40. g; Peltandripites sp. cf. P. tener Norris. Munkerup Mbr. (170588-2-3). DGU 1991-EBK-41. h; Tetraporina compressa Kondrat'ev. Munkerup Mbr. (180588-2-3). DGU 1991-EBK-42. 
Reworked palynomorphs:

Densosporites anulatus (Loose) Smith \& Butterworth, 1967

D. variabilis (Waltz 1938) Potonié \& Kremp, 1956

Diatomozonotriletes saetosus (Hacquebard \&

Barss) Hughes \& Playford, 1961

Lycospora pellucida (Wicher) Schopf, Wilson \& Bentall, 1944

L. pusilla (Ibrahim) Schopf, Wilson \& Bentall, 1944

L. spp.

Raistrickia nigra Love, 1959

Tripartites trilinguis (Horst) Smith \&

Butterworth, 1967

T. vetustus Schemel, 1950

\section{Discussion of selected taxa}

Use of the following species requires some comment regarding taxonomy and/or nomenclature.

Cingutriletes infrapunctus (Schulz) comb. nov.: fig. $9 \mathrm{j}$

Basionym: Stereisporites (Cingutriletes) infrapunctus Schulz 1970, p. 688, pl. 131, fig. 1.

The genus Cingutriletes Pierce 1961 was relegated by Schulz (1970) to a subgenus of Stereisporites. Morbey (1975) appears to have followed Potonié (1970) in disagreeing with such a subdivision of the genus because he illustrated (pl. 9, fig. 4) a specimen which he recorded as Cingutriletes infrapunctus (Schultz) Morbey 1975. This combination was not discussed but it has since been used by several authors. It is, however, invalid according to the International Code of Botanical Nomenclature (ICBN) because Morbey neither indicated, nor provided any information about a basionym. The transfer is, therefore, validated here.

Dicyclosporis bicollateralis (Rogalska) comb. nov.: figs $7 \mathrm{~g}, \mathrm{j}$

1956 Sporites bicollateralis Rogalska, p. 84. pl. 29 , figs $4-6$

1966. Stereisporites (Dicyclosporis) bicollateralis (Rogalska) Schulz, p. 79, pl. 3, figs 14, 15.

Jansonius \& Hills (1990, card 4642) followed Potonie (1970) and accepted the elevation of the subgenus Dicyclosporis Schulz to generic rank.
As a result it is necessary to make this new combination. This also applies to $D$. pseudoverrucatus, as follows:

Dicyclosporis pseudoverrucatus (Schulz) comb. nov.: figs $7 \mathrm{~h}$, i

1970 Stereisporites (Dicyclosporis) pseudoverrucatus Schulz, p. 693, pl. 133, figs 12-16.

Dicyclosporis radiatus (Schulz) Jansonius \& Hills 1990: figs $7 \mathrm{e}, \mathrm{f}$

As indicated above, Jansonius and Hills (1990, card 4642) followed Potonié (1970) and accepted the elevation of the subgenus Dicyclosporis to generic rank.

Distcyclosporis trizonatus (Schulz) Jansonius \& Hills 1990: fig. $7 \mathrm{k}$

Jansonius \& Hills (1990) again followed Potonié (1970) and accepted the elevation of the subgenus Distcyclosporis to generic rank. This emendation is followed here. Their misspelling of the specific epithet (as trigonatus) is regarded as an orthographic error.

Kraeuselisporites reissingeri: fig. $9 \mathrm{~d}$

According to Morbey (1975) the genus Heliosporites Schulz 1962 is, in exine structure and nature of ornamentation, identical with Kraeuselisporites Leschik 1955 emend. Jansonius 1962. The latter is, therefore, used for the species found in the Rønne material.

"Monosaccates": cf. Paleopicea glaesaria: fig. $10 \mathrm{a}$

This form is rare in the Munkerup Member but very characteristic, the sacci merging with each other equatorially to give the impression of a monosaccate pollen. Paleopicea glaesaria Bolkhovitina, 1956, which was originally described from the Lower Jurassic of the Yakutsk region, is very similar in size and form to the species found here. Closely comparable specimens have also been recorded as Monosaccate indet. by Dybkjær (1988, pl. 6, fig. 7), from the Lower Jurassic Fjerritslev Formation in the Gassum no. 1 well in the Danish subbasin (fig. 5).

Ovoidites sp. 1: fig. 12 a

The specimens recorded under this heading are smaller (length $60-70 \mu \mathrm{m}$, width $30 \mu \mathrm{m}$ ) than the 


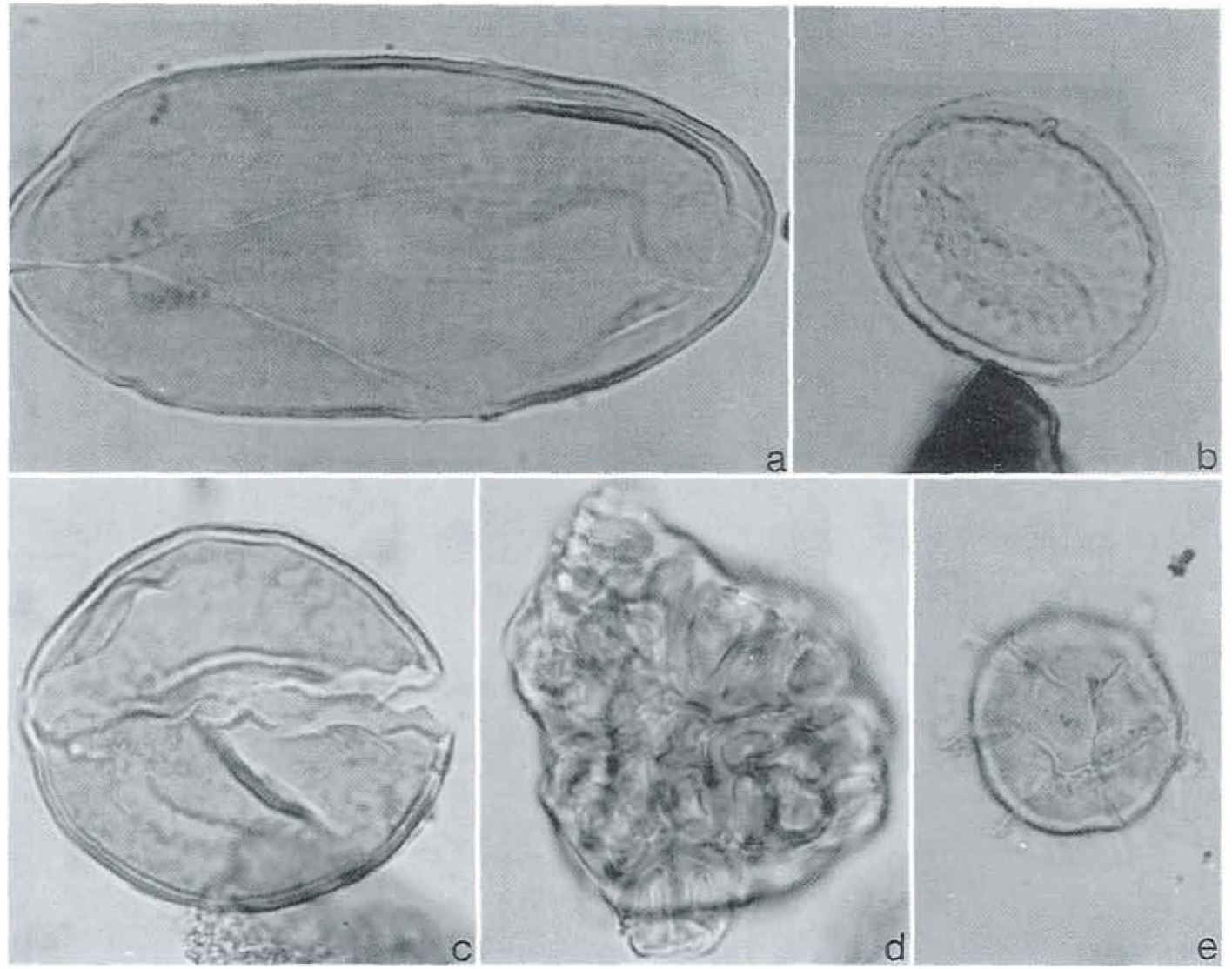

Fig. 12. a: Ovoidites sp. 1. Munkerup Mbr. (170588-2-3). DGU 1991-EBK-43. b; Lecaniella foveata Singh. Munkerup Mbr. (170588-5-3). DGU 1991-EBK-44, c; Ovoidites sp. 2. Munkerup Mbr. (170588-2-3). DGU 1991-EBK-45. d; Botryococcus sp. Sose Bugt Mbr. (241086-11-1). DGU 1991-EBK-46. e; Cymatiosphaera sp. Sose Bugt Mbr. (241086-18-1). DGU 1991-EBK-47.

type species, $O$. ligneolus Potonié ex Krutzsch 1959 , which is $130-135 \mu \mathrm{m}$ in length. They are elliptical, laevigate, and have a thin wall $(1.5 \mu \mathrm{m})$ which commonly divides into two equal halves along the long axis, although remaining attached at one point.

\section{Ovoidites sp. 2: fig. 12c}

This morphotype of the genus Ovoidites is circular, laevigate, has a wall that is $2.5 \mu \mathrm{m}$ thick, and is often partly split into two halves. It is nearly identical to Schizophacus spriggi (Cookson \& Dettmann) Pierce 1976.

Peltandripites sp. cf. P. tener Norris 1969: fig. $11 \mathrm{~g}$ This form is very common in the samples from the Munkerup and Sose Bugt Members. In the original diagnosis of the species (Norris, 1969) the surface is described as being covered with short, closely spaced, irregularly distributed spines. The specimens encountered in this study appear instead, however, to be sculptured with closely spaced granules.

Quadraeculina anellaeformis: fig. $10 \mathrm{e}$

The specimens of Quadraeculina recorded from the Rønne Formation show a rather large variation in size, ranging from 35 to $75 \mu \mathrm{m}$ in length and 30 to $62.5 \mu \mathrm{m}$ in width (55 specimens measured). Despite this they are all considered to fall within the circumscription of the species $Q$. anellaeformis.

Sculptisporis aulosenensis (Schulz) comb. nov.: fig. $7 \mathrm{c}$

1966 Stereisporites (Sculptisporis) aulosenensis Schulz, p. 77, pl. 3, figs 4-6

1967 Camarozonosporites (Camarozonosporites) aulosenensis Schulz, p. 573, pl. 7, figs 12-14 In common with their approach to Dicyclosporis 
and Distcyclosporis, Jansonius \& Hills (1990, card 4761) accepted the elevation of the subgenus Sculptisporis to generic rank previously made by Potonié (1970); hence this new combination here.

Striatella jurassica, S. scanica: figs $9 \mathrm{a}, \mathrm{b}$, and $S$. seebergensis: fig. $9 \mathrm{c}$

The diagnoses of these three species were emended by Filatoff \& Price (1988). Although there are intermediate specimens which can be very difficult to determine, there is no doubt that all three species are present in the Rønne material.

Tetraporina compressa Kondrat'ev, 1963: fig. $11 \mathrm{~h}$ The specimens recovered appear to be identical with one figured in Lund (1977, pl. 12, fig. 5), but not with his other specimen (pl. 10, fig. 7), which has four pores. Both were named Schizocystia cf. rara, but reference to Tetraporina compressa, which was described two years before $S$. rara, is preferred here. The Rønne specimens are also very similar to the Type A zygospores (Mougeotia cf. punctata) described by Van Geel (1976) from Quaternary deposits in the Netherlands. Extant Mougeotia occurs widely in fresh and brackish water.

Tigrisporites microrugulatus: figs $8 \mathrm{f}, \mathrm{g}$

This species has been used for a wide varity of morphotypes in the Rønne Formation, some of which are almost identical to the specimens described by Schulz (1967). Others that are not so closely comparable are, however, currently included in it, pending the outcome of further taxonomic analysis.

\section{Palynostratigraphy}

\section{Munkerup Member}

The seven samples from the Munkerup Member contain an assemblage of about 73 species of palynomorphs (see composite range chart, figs $3 \mathrm{a} \& \mathrm{~b}$ and 4). A number of these are long ranging spore and pollen species such as Deltoidospora toralis, Cerebropollenites thiergartii, Pinuspollenites minimus, and Perinopollenites ela- toides. Species with shorter ranges such as Kraeuselisporites reissingeri, Tigrisporites microrugulatus, Trachysporites fuscus, T. asper, T. sparsus, Zebrasporites interscriptus, Aratrisporites minimus, A. parvispinosus and Ovalipollis ovalis Krutzsch, 1955 have been found but are rare. All are typical of Rhaetian deposits, but they are also known to occur sporadically in Hettangian rocks (Lund, 1977; Dybkjær, 1988), and other taxa diagnostic of a Rhaetian age, such as Rhaetipollis germanicus Schulz, 1967 emend. Schuurman, 1977, Triancoraesporites ancorae Schulz, 1967, Limbosporites lundbladii Nilsson, 1958, and Riccisporites tuberculatus Lundblad, 1954 are absent. There are 6 species in the Munkerup assemblages which are common (more than 16-25 specimens in a count of 200); these are Chasmatosporites hians, Perinopollenites elatoides, Pinuspollenites minimus, Deltoidospora toralis, Calamospora tener and Alisporites robustus, the first four of which are also known to dominate equivalent assemblages of similar age from the Fjerritslev Formation in Rødby no. 1 borehole (Lund, 1977) and Stenlille no. 2 borehole (Dybkjær, in press; fig. 5 herein). The assemblages from the Fjerritslev Formation in Stenlille no. 2 are also dominated by Calamospora tener.

The assemblages found in the Munkerup Member are considered to be referable to Lund's (1977) Pinuspollenites-Trachysporites Zone which indicates a Hettangian age. This zone was established on the basis of a palynological study of the Rhaetic and lower Liassic sequence penetrated by the Rødby no. 1 well. It is known from the Fjerritslev Formation in the Gassum no. 1 well (Dybkjær, 1988) and in the Helsingborg Member of the Höganas Formation in the Valhall no. 1 well in southern Scania (Guy-Ohlson, 1981, fig. 7). In Stenlille no. 2 well the same assemblage is present but was referred to a Pinuspollenites-Deltoidospora Zone by Dybkjær (in press), because Lund's (1977) name seemed inappropriate in view of the fact that the assemblages she encountered contain very few Trachysporites species.

\section{Sose Bugt Member}

The eighteen samples from the Sose Bugt Member contain 97 species of palynomorphs (figs $3 \mathrm{a}$, b and 4). The long ranging spores and pollen recorded from the Munkerup Member also occur 
in this member. Among the new species appearing for the first time are a complex of small round to triangular sphagnalean spores belonging mostly to the genera Stereisporites, Annulispora, Sculptisporis, Dicyclosporis, Distcyclosporis, Rogalskaisporites, Cingutriletes, and Polycingulatisporites. Camarozonosporites golzowensis also occurs sporadically. Striatella scanica is common in two samples, one in the lower part of the member and one in the upper part; in the latter it occurs together with Striatella jurassica. The spore Laevigatosporites dubius is very common throughout the member. In the upper part (from samples 24108606 to 24108618; fig. 4) Cerebropollenites macroverrucosus and Retitriletes semimuris appear sporadically. Clavatipollenites hughesii is abundant in sample 24108610 in association with only three other palynomorph species.

The assemblages recovered from the Sose Bugt Member can be divided into two groups, those from the lower part again being referable to Lund's (1977) Pinuspollenites-Trachysporites Zone, indicating a Hettangian age. Those from the upper part correlate with Dybkjær's (in press) Cerebropollenites macroverrucosus Zone, the age of which is suggested to be Sinemurian on the basis of the presence of Cerebropollenites macroverrucosus.

According to Schulz (1970) there is an acme of sphagnalean spores in the lower to upper Sinemurian which he considered might be useful in distinguishing the Sinemurian stage from the Pliensbachian. Coupled with the appearance of Cerebropollenites macroverrucosus this acme might also be used to diferentiate between the Sinemurian and the Hettangian, but it is still not possible to distinguish the lower from the upper Sinemurian. Abundances of Clavatipollenites hughesii are unusual in the Hettangian and Sinemurian but, although perhaps having (unknown) palaeoecological implications, the occurrence of numerous specimens in one of the samples noted above is not regarded as stratigraphically significant because the species is known to be sporadically common elsewhere. Lund (1977) has recorded a few $(0,3 \%)$ in Rødby no. 1 borehole and Dybkjær (in press) also encountered some in the Fjerritslev no. 2 and Frederikshavn no. 2 boreholes in the Danish subbasin. Guy-Ohlson (1981) recorded numerous $C$. hughesii from the upper Rhaetian in Valhall no. 1 in the southern part of
Sweden. The species is also known from the lower Lias of East Germany (Schulz, 1967).

\section{Galgeløkke Member}

The nine samples from the Galgeløkke Member yielded 67 species of palynomorphs, 33 spore types of which 5 are reworked Carboniferous forms, 29 pollen and 5 aquatic palynomorphs. Many of the trilete spores recorded from Munkerup and Sose Bugt Members were not encountered in this unit, and no new taxa were noted apart from Carboniferous spores (Nielsen \& Koppelhus, 1991) which seem to be more common in this member than in the other two. Trilete, laevigate spores generally dominate the assemblages. There are fewer pollen grains than in the other members, but species such as Alisporites thomasii, $A$. robustus, Chasmatosporites hians, Perinopollenites elatoides, and Pinuspollenites minimus are abundant. Furthermore, Botryococcus seems to be consistently present throughout the sequence.

Overall, however, the assemblages encountered in the Galgeløkke Member are similar to those in the upper part of the Sose Bugt Member and all appear to correlate with the Cerebropollenites macroverrucosus Zone (Dybkjær, in press). They could have been deposited at the same time but in different environments. This suggestion might be supported by the fact that to date the Galgeløkke Member is known to be present only on the Rønne-Hasle Block and not on the Arnager-Sose Block.

\section{Palaeoenvironment}

As indicated in the discussion of the palynostratigraphy, there are a number of miospores which are not only long-ranging but also common to abundant in most of the assemblages examined. These are mainly of gymnospermous origin and include species of Alisporites, Cerebropollenites, Chasmatosporites, Corollina, Perinopollenites and Pinuspollenites, but smooth-walled trilete spores referable to Deltoidospora are also common, and other trilete forms such as Baculatisporites comaumensis and Lycopodiacidites rugulatus are sporadically numerous. This association is typical of assemblages encountered in Lower Ju- 
rassic rocks elsewhere in north-west Europe (e.g. Ainsworth et al., 1989) and suggests that much of the vegetation of this region was dominated by gymnosperms. The generally good state of preservation implies a mainly local source.

Superimposed on this are, however, some indications of a change in the vegetation which may also have climatic implications (cf. Batten \& Lister, 1988). The most significant of these is suggested by the influx of Stereisporites in the Sose Bugt Member which, in addition to being of stratigraphic value, also reflects an increase in the importance of plants referable (on present evidence) to the Sphagnales. This in turn coincides with sedimentological evidence of a change from lacustrine conditions (Munkerup Member) to a delta plain environment dominated by fluvial deposition. A relative increase in the number of presumed freshwater algae supports this interpretation. Similar changes have been recorded in the non-marine Early Cretaceous, Wealden succession of south-east England (Batten, 1982; Batten \& Lister, 1988).

The reduced diversity of the assemblages recovered from the Galgeløkke Member by comparison with those recorded from the underlying members, and the reversion to domination by trilete, laevigate spores and gymnosperm pollen is not easy to explain. It may reflect a combination of factors including increased distance from source vegetation, which would have meant a longer period of transport of the palynomorphs prior to deposition, and a change to a transgressive sedimentary regime. Again there is a basis for comparison with Wealden data. Batten (1975) found that the assemblages typical of the more transgressive phases of deposition of the Hastings Beds were mainly dominated by gymnosperm pollen and small, unornamented trilete spores, and that during regressions the diversity of the pteridophyte spore assemblages increased markedly. Such comparisons, although lending support to the general suggestions made here, are not meant to imply, however, that the palaeoecology and depositional environments of the Lower Jurassic of Bornholm and the Wealden Cretaceous were necessarily closely comparable.

\section{Conclusions}

It has been possible to distinguish between the three members of the Rønne Formation on the basis of relative abundances of some of the palynomorphs and to a lesser extent on changes in composition, especially of several species of the genus Stereisporites in the Sose Bugt Member. The fact that many forms cease to occur in the Galgeløkke Member is probably connected with a change in environment. From a palynological viewpoint it is not possible to conclude that the sediments from the Galgeløkke Member are younger than those from the upper part of the Sose Bugt Member; they could be at least partly synchronous (fig. 6).

The palynomorph assemblages recovered from the Rønne Formation correlate well with those of other Lower Jurassic deposits in Denmark (Rødby no. 1; Lund 1977; Gassum no. 1, Dybkjær, 1988) southern Sweden (Valhall no. 1; Guy Ohlson, 1981), the Netherlands (e.g. Herngreen, 1974), Great Britain (e.g. Orbell, 1973), Germany (Eitzendorf no. 8; Lund 1977; also Schulz, 1967, 1970; Achilles, 1981), and Poland (e.g. Marcinkiewicz, 1971).

The depositional environment of the earliest Jurassic on Bornholm (Munkerup Member) has been interpreted as lacustrine followed by a prograding, fluvially dominated delta plain (Sose Bugt and Galgeløkke Members; Gravesen et al. 1982; L. H. Nielsen, pers. comm. 1989). The palynological data on the three members in the Rønne Formation support this interpretation. The assemblages are dominated by spores and pollen grains; only a few brackish-water indicators have been recovered. The good preservation of the palynomorphs suggests that they were deposited in a low energy environment only a short distance from, or adjacent to the source vegetation.

Acknowledgements. The paper was written during my first year of research for a $\mathrm{PhD}$, supported by a grant from Carlsbergfondet (88-0207/20), and during a 6 month stay at the Institute of Earth Studies, University College of Wales, Aberystwyth, supported by the Danish Research Academy and supervised by D. J. Batten (UCW). D. J. Batten is thanked for valuable discussions and critical reading of the manuscript. $O$. Michelsen, S. Piasecki and L.H. Nielsen are thanked for comments and discussions in the final stage of the work. 


\section{Dansk sammendrag}

En palynologisk analyse af aflejringerne fra nedre jura på Bornholm har resulteret i en rig polynomorf flora af hettangien og sinemurien alder. Ialt 34 prøver fra typelokaliteterne for Munkerup, Sose Bugt og Galgeløkke Member er blevet undersøgt. Formålet med arbejdet har været at revaluere den etablerede stratigrafi defineret af Gry (1969) og Graversen et al. (1982) of karakterisere de tre Member ved hjælp af palynomorfer. 108 taxa er blevet registreret hvoraf 67 er sporer, 19 pollen og 7 akvatiske palynomorfer. Mange af disse er stratigrafisk vigtige arter, men sammensætningen af den relative hyppighed af et lille antal udvalgte arter kan bruges til at skelne mellem de tre Member. Palynomorf floraen fra Munkerup Member og nedre del af Sose Bugt Member er henført til Lunds (1977) Pinuspolleenites-Trachysporites Zonen, $\emptyset \mathrm{vre}$ del af Sose Bugt Member og Galgeløkke Member er korreleret til Cerebropollenites inacroverrucosus Zonen, Dybkjær (in press). De palynologiske data fra alle tre Member af Rønne Formationen støtter de tidligere aflejringsmodeller, som indikerer lakustrine og flodslette aflejringsmiljøer.

\section{References}

Achilles, H., 1981: Die rätische und liassische Mikroflora Frankens. Palaeontographica Abt. B179, 1-86, 17 pls.

Ainsworth, N. R., O'Neill, M.O. and Rutherford, M.M., 1989: Jurassic and Upper Triassic biostratigraphy of the North Celtic Sea and Fastnet Basins. In Batten, D. J. \& Keen, M.C. (eds.): Northwest European Micropalaeontology and Palynology. Ellis Horwood Limited, 1-49.

Batten, D. J., 1975: Wealden palaeoecology from the distribution of plant fossils. Proc. geol. Ass. 85, 433-458, 1 pl.

Batten, D. J., 1982: Palynofacies and salinity in the Purbeck and Wealden of southern England. In Banner, F.T. \& Lord, A. R.: Aspects of Micropalaeontology. George Allen \& Unwin, 278-308.

Batten, D. J. \& Lister, J., 1988: Evidence of freshwater dinoflagellates and other algae in the English Wealden (Early Cretaceous). Cretaceous Research 9, 171-179.

Bolkhovitina, N. A., 1956: Atlas of spores and pollen of the Jurassic and Lower Cretaceous of the Vilui depression. Trudy Inst. Geol. Nauk. Mosk., 2, 1-132, 25 pls (in Russian).

Christensen, O.B., 1972: Det danske sænkningsområdes udvikling i det mellemste Mesozoicum. Dansk Geol. Foren., Årskrift 1971, 55-62.

Cookson, I. C., 1947: Plant microfossils from the lignites of Kerguelen Archipelago. B.A.N.Z. Antarc. Res. Exped. 1929-1931. Rep. Ser. A.II 8, 127-142, 5 pls.

Cornet, B. \& Traverse, A., 1975: Palynological contributions to the chronology and stratigraphy of the Hartford Basin in Connecticut and Massachusetts. Geoscience and Man, 11, $1-33$.

Couper, R. A., 1958: British Mesozoic microspores and pollen grains. A systematic and stratigraphic study. Palaeontographica Abt. B 103, 75-179, 16 pls.

Danzé-Corsin, P. \& Laveine, J.-P., 1963: Flore Infraliasique du Boulonnais (Macro et Microflore). Soc. Geol. du Nord. Mem. 13, 7-137.

De Jersey, N. J., 1959: Jurassic spores and pollen grains from the Rosewood Coalfield. Geol. Surv. Queensland Publ. 294, 2-14.

Dettmann, M. E., 1963: Upper Mesozoic microfloras from south-eastern Australia. Proc. Roy. Soc. Victoria. New Ser. 77(1), 1-148.
Döring, H., Krutzsch, W., Schulz, E. \& Timmermann, E., 1966: Über einige neue Subformgenera der Sporengattung Stereisporites Th. \& Pf. aus dem Mesozoikum und Alttertiär Mitteleuropas. Geol. Jahrg. 15(55): 72-89.

Döring, H., Krutzsch, W., Mai, D. \& Schulz, E., 1963: Diskussionsbeitrag zur Sporengattung Retitriletes. In: Krutzsch, W., 1963: Atlas der mittel- und jungtertiären dispersen Sporen- und Pollen sowie der Mikroplankton formen des nordlichen Mitteleuropas. V.E.B. Deutsch. Verl. Wiss. Berlin, 8-18.

Dybkjær, K., 1988: Palynological zonation and stratigraphy of the Jurassic section in the Gassum No. 1-borehole, Denmark. Geol. Surv. Denm. Ser. A 21, 1-73.

Dybkjær, K. (in press): Palynological zonation and palynofacies investigation of the Fjerritslev Formation, Lower Jurassic - Basal Middle Jurassic in the Danish Subbasin. Geol. Surv. Denm. Ser. A 30.

Erdtman, G., 1948: Did dicotyledonous plants exist in Early Jurassic times? Geol. Foren. Forhandl. 70(2), 265-271.

Filatoff, I., 1975: Jurassic palynology of the Perth Basin, Western Australia. Palaeontographica Abt. B 154, 1-113, 30 pls.

Filatoff, I. \& Price, P. L. 1988: A pteridacean spore lineage in the Australian Mesozoic. Mem. Ass. Austral. Palaeontols. $5,89-124$.

Gravesen, R., Rolle, F. \& Surlyk, F., 1982: Lithostratigraphy and sedimentary evolution of the Triassic, Jurassic and Lower Cretaceous of Bornholm, Denmark. Geol. Surv. Denm. Ser. B 7, 1-51.

Gry, H., 1969: Megaspores from the Jurassic of the island of Bornholm. Medd. Dansk Geol. Foren. 19, 69-87.

Grönwall, K. A. \& Milthers, V., 1916: Kortbladet Bornholm. Danm. Geol. Unders., I rk., 13, 281 pp.

Guy-Ohlson, D., 1981: Rhaeto-Liassic palynostratigraphy of the Valhall bore No. 1, Scania. Geol. Foren. Stockh. Forh. 103, 233-248.

Harris, T.M., 1937: The fossil flora of Scoresby Sound, East Greenland, Part 5: stratigraphic relations of the plant beds. Medd. Grønland 112 (2), 114 pp.

Herngreen, G. F. W. \& de Boer, K. F., 1974: Palynology of Rhaetian, Liassic and Dogger Strata in the eastern Netherlands. Geologie en Mijnbouw 53, 343-368.

Huckriede, R., 1967: Molluskenfaunen mit limnischen und brackischen Elementen aus Jura, Serpulit und Wealden NW-Deutschlands und ihre palaeogeographische Bedeutung. Beih. Geol. Jb. 67, 263 pp. 25 pls.

Hughes, N.F. \& Playford, G., 1961: Palynological reconnaissance of the Lower Carboniferous of Spitsbergen. Micropaleontology 7, 27-44.

Jansonius, J., 1962: Palynology of Permian and Triassic sediments, Peace River area, western Canada. Palaeontographica Abt. B 110, 35-98, 6 pls.

Jansonius, J. \& Hills, L. V., 1990: Genera file of fossil spores. Supplement 10. Spec. Publ. Univ. Calgary, Canada.

Jung, W., 1958: Zur Biologie und Morphologie einiger disperser Megasporen vergleichbar mit solchen von Lycostrobus scotti, aus dem Rhat-Lias Frankens. Geologische Blatter für Nordost-Bayern. 8: 114-130.

Jung, W., 1960: Die dispersen Megasporen der Frankischen Rhät-Lias-Grenzschichten. Palaeontographica Abt. B 107. 127-170.

Kemp, E., 1970: Aptian and Albian miospores from southern England. Palaeontographica Abt. B 131, 73-143, 20 pls.

Klaus, W., 1960: Sporen der karnischen Stuffe der ostalpinen Trias. Geol. Jb. B. A. Sonderb. 5, 107-184, 10 pls.

Kondrat'ev, G. K., 1963: The first finds of Angiospermae-type pollen in Upper Paleozoic beds of the Tunguska Basin. Akad. Nauk. SSSR, Siberian Div., Geol. Geophys. 12, 63-72, 2 pls (In Russian). 
Krutzsch, W., 1955: Über einige liassische "angiospermide" Sporomorphen. Geologie 4, 65-76, 4 pls.

Krutzsch, W., 1959: Mikropaläontologische (sporenpaläontologische) Untersuchungen in der Braunkohle des Geiseltales. Geologie 8, 1-434, 49 pls.

Krutzsch, W., 1963: Atlas der mittel- und jungtertiaren dispersen Sporen- und Pollen-sowie der Mikroplanktonformen des Nordlichen Mitteleuropas. Lief II, III, V.E.B. Deutsch. Verl. Wiss. Berlin, 141 pp; 128 pp.

Leschik, G., 1955: Die Keuperflora von Neuewelt bei Basel. II Die Iso- und Mikrosporen. Schweiz. Palaeontol. Abh. 72, $1-70,10$ pls.

Love, L. G., 1959: Assemblages of small spores from the Lower Oil-Shale Group of Scotland. Proc. Roy. Soc. Edinb. 67 B, 1958-59, Part II, 99-126.

Lund, J. J., 1977: Rhaetic to lower Liassic palynology of the onshore south-eastern North Sea Basin. Danm. geol. Unders., II rk., 109, 1-129.

Lund, J. J. \& Ecke, H.-H., 1988: Dinoflagellate cyst stratigraphy applied to the Middle to Late Jurassic of the Regensburg-Passau area, Bavaria. Bull. Centres Rech. Explor.Prod. Elf-Aquitaine 12-1 og 345-359.

Lundblad, B., 1954: Contributions to the geological history of the Hepaticae. Svensk. Bot. Tidskr. 48, 381-417.

Malyavkina, V.S., 1949: Key to spores and pollen from the Jurassic and Cretaceous. Trudy VNIGRI 33, 1-137. (In Russian).

Marcinkiewicz, T., 1971: Stratygrafia retyku i liasu w Polsce na podstawie badan megasporowych. Pr. Inst. Geol. 65, 37 pp.

McKellar, J. L., 1974: Jurassic miospores from the upper Evergreen Formation, Hutton Sandstone, and basal Injune Creek Group, north-eastern Surat Basin. Geol. Surv. Queensland 361, 1-89, 13 pls.

Michelsen, O., 1989: Revision of the Jurassic lithostratigraphy of the Danish subbasin. Geol. Surv. Denm. Ser. A 24, 23 pp.

Morbey, S. J., 1975: The palynostratigraphy of the Rhaetian Stage, Upper Triassic in the Kendelbachgraben, Austria. Palaeontographica Abt. B 152, 1-75, 19 pls.

Mädler, K., 1964a: Die geologische Verbreitung von Sporen und Pollen in der Deutschen Trias. Beih. Geol. Jahrb. 65, $147 \mathrm{p}, 12$ pls.

Mädler, K., 1964b: Bemerkenswerte Sporenformen aus dem Keuper und unteren Lias. Fortschr. Geol. Rheinld. Westf. $12,169-200,3$ pls.

Nielsen, L. H., \& Koppelhus, E. B., 1991: Reworked Carboniferous palynomorphs from Lower Jurassic Bornholm and their palaeogeographic significance. Bull. geol. Soc. Denmark, 38, 253-266.

Nilsson, T., 1958: Über das Vorkommen eines mesozoischen Sapropelgesteins in Schonen. Lunds Univ. Arsskr. N.F. Avd. 2, 54(10), 1-111.

Norris, G., 1965: Triassic and Jurassic miospores and acritarchs from the Beacon and Ferrar Groups, Victoria Land, Antarctica. N. Z. J. Geol. Geophys. 8, 236-277.

Norris, G., 1969: Miospores from the Purbeck Beds and marine Upper Jurassic of southern England. Palaeontology 12, 574-620.

Orbell, G., 1973: Palynology of the British Rhaeto-Liassic. Bull. Geol. Surv. G. B. 44, 1-33, 5 pls.

Orlowska-Zwolinska, T., 1966. Lower Liassic age of the Welichowo beds in the light of spore-and-pollen analysis (Polish Lowland). Kwartalnick Geologiczny 10, 1003-1022.

Pierce, R. L., 1961: Lower Upper Cretaceous plant microfossils from Minnesota. Bull. Minnes. Geol. Surv. 42, 86 pp.

Pierce, S.T., 1976: Morphology of Schizosporis reticulatus Cookson and Dettmann 1959. Geoscience and Man 15, 25-33.

Playford, G. \& Dettmann, M. E., 1965: Rhaeto-Liassic plant microfossils from the Leigh Creek Coal Measures, South Australia. Senckenberg. Leth. 46, 127-181.

Pocock, S. A. J., 1962: Microfloral analysis and age determination of the strata at the Jurassic-Cretaceous boundary in the western Canada plains. Palaeontographica Abt. B 111, $1-95,15$ pls.

Pocock, S. A. J., 1970: Palynology of the Jurassic sediments of western Canada. Part 1. Terrestrial species. Palaeontographica Abt. B 130, 12-136, 12 pls.

Potonié, R., 1956: Synopsis der Gattungen der Sporae dispersae. Teil I. Beih. Geol. Jb. 23, 103 pp.

Potonić, R., 1970: Synopsis der Gattung der Sporae dispersae. Teil V. Beih. Geol. Jb. 87, 222 pp.

Potonié, R. \& Kremp, G. O.W., 1956: Die Sporae Dispersae des Ruhrkarbons, ihre Morphographie und Stratigraphie mit Ausblicken auf Arten anderer Gebiete und Zeitabsnitte. Teil III. Palaeontographica Abt. B 100, 65-121.

Poulsen, N. E., Gudmundson, L., Hansen, J. M. \& Husfelt, Y. 1990: Palynological preparation techniques, a new macerationtank-method and other modifications. Geol. Surv. Denm. Ser. C. 10, 22 pp.

Reinhardt, P., 1961: Sporae dispersae aus dem Rhät Thüringens. Mbr. dt. Akad. Wiss. Berl. 3(11/12), 704-711.

Rogalska, M., 1956: Spore and pollen analysis of the Liassic deposits of the Mroczkow-Rozwady area in the Opoczno district. Inst. Geol. Biul. Warszawa 104, 89 pp, 32 pls.

Rolle, F., 1978: Sedimentationsmiljøer i nedre Jura på Bornholm. Unpublished thesis, University of Copenhagen $85 \mathrm{pp}$.

Schemel, M. P., 1950: Carboniferous plant spores from Daggett County, Utah. J. Paleont. 24, 232-244, 2 pls.

Schopf, J., Wilson, L. \& Bentall, R., 1944: An annotated synopsis of Paleozoic spores and the definition of generic groups. Illinois Geol. Surv. Rep. Inv. 91, 73 pp, 3 pls.

Schulz, E., 1962: Sporenpaläontologische Untersuchungen zur Rhät-Lias Grenze in Thüringen und der Altmark. Geologie 11, 308-309.

Schulz, E., 1966: In Döring, H., Krutzsch, W., Schulz, E. \& Timmermann, E.: Über einige neue Subformgenera der Sporengattung Stereisporites Th. \& Pf. aus dem Mesozoikum und Alttertiar Mitteleuropas. Geol. Jahrg. 15: 72-89.

Schulz, E., 1967: Sporenpaläontologische Untersuchungen rätoliassischer Schichten im Zentralteil des Germanischen Beckens. Paläontol. Abh. B 2(3), 541-633.

Schulz, E., 1970: Die Sporen der Gattung Stereisporites Thomson \& Pflug, 1953 aus dem älteren Mesophyticum des Germanischen Beckens. Paläontol. Abh. B III 3/4, 683709,10 pls.

Schuurman, W. M. L., 1977: Aspects of Late Triassic Palynology 2. Palynology of the "Gres et Schiste A' Avicula Contorta" and "Argiles de Levallois" (Rhaetian) of northeastern France and southern Luxembourg. Rev. Palaeobot. Palynol. 23, 159-253.

Sellwood, B. W., 1972: Tidal-flat sedimentation in the Lower Jurassic of Bornholm, Denmark. Palaeogeogr, Palaeoclimatol., Palaeoecol., 11, 93-106.

Singh, C. 1971: Lower Cretaceous microfloras of the Peace River area, northwestern Alberta. Research Council of Alberta Bull. 28(2), 301-542.

Singh, H. P., 1964: A miospore assemblage from the Permian of Iraq. Palaeontology 7, 240-265, 3 pls.

Sivhed, U., 1984: Litho- and biostratigraphy of the Upper Triassic-Middle Jurassic in Scania, southern Sweden. Sver. Geol. Unders., Ser. C, 806, 31 pp.

Smith, A. H. V. \& Butterworth, M. A., 1967: Miospores in the coal seams of the Carboniferous of Great Britain. Spec. Pap. Palaeont. 1, 324 pp, 27 pls.

Surlyk, F. \& Noe-Nygaard, N., 1986: Hummocky cross strati- 
fication from the Lower Jurassic Hasle Formation of Bornholm, Denmark. Sedimentary Geology 46, 259-273.

Thomson, P. W. \& Pflug, H., 1953: Pollen und Sporen des mitteleuropäischen Tertiärs. Palaeontographica Abt. B 94, 1-138.

Van Geel, B., 1976: Fossil spores of Zygnemataceae in ditches of a prehistoric settlement in Hoogkarspel (The Netherlands). Rev. Palaeobot. Palynol. 22, 337-344.

Weyland H. \& Krieger W. 1953: Die Sporen und Pollen der Aachener Kreide und ihre Bedeutung für die Charakterisierung des mittleren Senons. Palaeontographica Abt. B $95,6-29,5$ pls. 